\title{
Appraisal of Abiogenic Oil (Petroleum) using Mathematical Modeling Approach with certain selected Elements, Minerals and Rocks of Kassa Volcanic Field (KVF) of Jos Plateau State, Nigeria
}

\author{
Achuenu Ifeanyi ${ }^{1}$, Joro Joshua Dung ${ }^{2}$, and IZEZE EIIJAH OVIE ${ }^{3}$ \\ ${ }^{1}$ Technologist, ${ }^{2}$ Lecturer, \\ Department of Mining Engineering, University of Jos, Nigeria \\ ${ }^{3}$ Lecturer, Department of Earth Science, Federal University of Petroleum Resources, Effurun \\ Delta State, Nigeria
}

\begin{abstract}
The possibility of finding petroleum hydrocarbons in sedimentation (sedimentary rock) or magmatic-hydrothermal (igneous origin) is a matter of probability. A mathematical modeling approach is employed to appraise petroleum hydrocarbons using certain elements, minerals, and rocks whether it is biogenic or abiogenic. Methodologically, ten samples were collected at random at different points in Kassa Volcanic Field (KVC). These samples were examined in a thin section in the University of Jos Geology laboratory, using a petrographic microscope both plane and crossed polarized light and the minerals revealed were olivines, pyroxene, plagioclase, and iron ore. Two kilograms $(2 \mathrm{~kg})$ of each of the samples were pulverized and subjected to chemical analysis using inductively coupled plasma - Mass spectrometer (ICP-MS) and revealed the following major and trace elements such as, as $\mathrm{Si}, \mathrm{Al}, \mathrm{Fe}, \mathrm{Mg}, \mathrm{Ca}, \mathrm{K}, \mathrm{Na}, \mathrm{P}, \mathrm{N}, \mathrm{Ni}, \mathrm{Va}, \mathrm{Ti}, \mathrm{Mo}, \mathrm{As}, \mathrm{Ba}, \mathrm{Ca}, \mathrm{Sc}, \mathrm{Cr}, \mathrm{Br}$, in percentage and in part per million and can be compared to those obtained from petroleum ash. Several experiments have shown that petroleum ash contains the following major and trace elements: Silicon, Iron, Aluminum, Calcium, Magnesium, Copper, Lead, Tin, Arsenic, Antimony, Zinc, Silver, Nickel, Chromium, Molybdenum, Bismuth, and Vanadium. Using set notation and matrix approach to analyze these elements, three possibilities were made to trace the origin of petroleum hydrocarbon whether it is a sedimentary origin (biogenic) or igneous origin (abiogenic). Mathematically, these possibilities include; the SiAl consisting of Silicon and Aluminum, the TiTi consisting of Tin and Titanium as well as NiVa, consisting of Nickel and Vanadium. Another important possibility is the presence of Diamond within an igneous body which depicts the characteristic of mantle composition. The ability of this abiogenic oil to rotating the plane of polarization of polarized light was examined and was proven possible using the mathematical method. The presence of these three possibilities in the crude oil could be a result of infiltration of these minerals and elements, from the source igneous rocks during crystallization of magma. If the abiogenic origin using the three possibilities is considered as the origin of petroleum, then drilling of petroleum hydrocarbons should be extended to the igneous environment, especially the study area Kassa Volcanic Field (KVF).
\end{abstract}

Keywords: Abiogenic Oil, Hydrocarbons, Polymerization, Matrix, Set Notation.

\subsection{INTRODUCTION}

\subsection{Background to the Study}

Carbon and silicon are the most unique elements as far as this research is concerned. They are found in group 4 of Mendeleev periodic table of an element. Their uniqueness is their ability to catenate with other elements to form complex compounds. While silicon catenates with other elements to form complex silicate minerals, carbon catenates with other elements to form complex hydrocarbon minerals. While silicon is a silicate rock former, carbon is a hydrocarbon former during crystallization of magma. Group 4 elements typically form four bonds .Carbon can form $\mathrm{p} \pi$-p $\pi$ double bond and $\mathrm{CO} 2$ is a discrete molecule and is a gas. Silicon cannot form double bond in this way using $\mathrm{p} \pi$-p $\pi$ orbitals. A substantial number of silicon compounds are now known to contain $\mathrm{p} \pi-\mathrm{d} \pi$ bonds in which the silicon atom appears to use d-orbital for bonding. Goldschmidt,(1914) states that carbon and silicon have a high melting point because of their high covalent bonding among all other non-metals in the periodic table. The presence of silica mineral in rocks increases the acidic content of the rocks, says from the basic to acidic rocks and hence increases the viscosity of the magma as temperature reduces during crystallization of magma. This gives rise to volatile component of the rock e.g., amphiboles and micas. Hydrogenation of Carbon on the other hand, increases the viscosity of hydrocarbons, from the 
lighter gas to heavier asphalt (aromatic) and the heavier crude can also be cracked to obtain the lighter gas vice versa. The process in which lighter crude changes to heavier crude in the presence of certain inorganic catalysts is called polymerization and this takes place during the formation of abiogenic hydrocarbon from magmatic or hydrothermal fluid. The process in which the heavier crude (less volatile component) changes to lighter crude when heated under high temperature and put under high pressures either in the presence or absence of organic catalysts is called cracking and this also takes place during the formation of biogenic hydrocarbon from kerogen.

Mathematical models involve the use of equations consisting of variables and constants according to Hubbert (1937). Geomathematics, in its broadest sense includes all applications of mathematics to studies of the earth's crust.

In geomathematical problems, one usually asks if there are theoretical reasons to assume the certain variables are related to one another and if theoretical geology can provide guidelines for statistical models to be fitted to the data. Generally, the geologist can observe and reconstruct only part of a very complicated process involving many variables that have taken place in the course of time under changing circumstances.

In practice, the resulting mathematical model may then consist of fitting to the data a few linear terms out of a Taylor expansion ([2.21]) for the mainly unknown geological process. Quantitative geologic considerations are indispensible, first for selection of the variables to be measured, for designing the mathematical model and later for interpretation and evaluation of the results.

Modeling is process of representing a real world object as set mathematical equations that is representing three dimensional objects especially in computer (ford, 2009). Mathematical models involve the use of equations consisting of variables and constants according to Hubbert (1937). Krumbein and Grayhill (1965) have distinguished three types of models in geology: (1) scale-models; (2) conceptual models; and (3) mathematical models. According to Nakayama and Vansiclen, (1981); Ungerer et al., (1984), deterministic models seek to identify and quantify all variables of the system and thus predict its behaviour by establishing values or limit for each system. Mathematical modeling in this context is the application of mathematical equations of numerical values to chemical elements in its algebraic form to produce a material of a particular IUPAC nomenclature according to Achuenu, (2021).

The carbon considered in this research is purely abiogenic particularly from magmatic origin as donors of carbon itself, carbonate and carbon dioxide as according to Hazen et al, (2012), which catenates with other elements to form complex hydrocarbons.

At the end of crystallization, all the other crystals have been fractionated within their stability limit and removed from the melt, therefor the remaining fluid called hydrothermal fluid, becomes highly volatile which contains fugitive elements, such as water, $\mathrm{CO}_{2}$, chlorine, lithium, fluorine and so on and these elements coincide with mantle gases at the depth of $80-100 \mathrm{~km}$. Among the elements, $\mathrm{CO}_{2}$ and $\mathrm{H}_{2} \mathrm{O}$ are the starting material for hydrocarbon in the magmatic environment.

The general molecular formula of first member of hydrocarbon minerals from abiogenic origin is $X_{n} Y_{2 n+2}$, where $n$ is the repeated number of molecule and

$$
\begin{aligned}
& X=\text { carbon } \\
& Y=\text { hydrogen }
\end{aligned}
$$

The formula above is used to calculate all the alkane groups from the magmatic rock and at $n=1, X_{n} Y_{2 n+2}$, justifies saturated hydrocarbon, methane, the first hydrocarbon to be liberated from magmatic rock during crystallization of magma. The only known source of methane is through inorganic reactions. According to J.F. kenney, and others, of the Russian state university of oil and gas, that methane is the only organic hydrocarbon to exist within Earth's crust. The report also discussed the hypothesis that high pressure of 25 to 50 kilobar or more are needed for establishing natural petroleum hydrocarbon molecule. Quantities of saturated hydrocarbons heavier than methane, on analogy with kutcherov et al, (2002) should decrease dramatically with an increase in molecular weight of hydrocarbons. Kutcherov et al., 2010 experimental result, shows that after cooling for 4 hours, the amount of $\mathrm{CH}_{4}$ and $\mathrm{C}_{2} \mathrm{H}_{6} / \mathrm{C}_{2} \mathrm{H}_{4}$ in the reaction production increases by factor of tens and heavier hydrocarbons up to $\mathrm{C}_{4} \mathrm{H}_{10} / \mathrm{C}_{4} \mathrm{H}_{8}$.

During fractional distillation of crude oil, temperature rises with increasing number of carbon content in the liquid fractions. Crude oil obtained from the ground is just about useless, proves its worth when, it must undergo fractional distillation first, just as the entire magmatic rocks are useless, until they transformed into an ore deposit e.g., Cassiterite and then undergoes mineral processing to liberate valuable minerals from the ore. Unlike the magmatic rocks that crystallize with falling temperature into fractions, crude oil distils over, with increasing temperature into fractions, a process called cracking of crude oil. This fraction is 
called fractionating column. The crude oil preheated to about $400^{\circ} \mathrm{c}$ in an electric furnace where $75 \%$ of the crude oil is vapourized. The temperatures at which each fraction distils over, ranges from the lower boiling point $40^{\circ} \mathrm{C}$, to the bottom of the column $\left(400^{\circ} \mathrm{C}\right)$.

Biogenic origin of petroleum inspires the possibility of exhausting oil reserves and abiogenic hypothesis assure quasiunlimited supplies of oil and gas reserves. Therefore many issues regarding energy renewability rises. According to the website petroleum, co.uk, (2014) politics as the main driver of every issue in our modern socio-economic aspects of living, the arguments of abiogenic versus biogenic origins of petroleum cause some hidden reasons which are particular interests and political motivated for example, "a limited supply can be used to control people and as justification for actions like war". An unlimited supply on the other hand, means that we ought to be able to drill for more oil and increase daily so as to decrease price and so forth (Petroleum Co.UK, 2014).

In conclusion, the duplex theory, which combines the features of both inorganic (abiogenic) and organic (biogenic) theories maybe the final choice according to Robinsoon (1963). On these hypotheses, the present stock of petroleum hydrocarbons would represent biogenic additions to a fundamentally primordial endowment. This would perhaps involve the enrichment of existing petroleum hydrocarbon deposits of biogenic source through a fundamentally abiogenic origin according to Abbas (1996).

\section{2: JUSTIFICATION}

The justification that hydrocarbons are of inorganic origin or organic would continue to evolve since nobody was there when these hydrocarbons were formed and it is matter of probability and available evidences using certain geochemical equipment.

The probability that hydrocarbons are of organic or inorganic origin is based on the fact that,

1. The ability of hydrocarbons to rotate under plane polarized light due to the presence of cholesterol which only happens in organic substances and

2. The presence of porphyrins in the kerogen or heavy crude was also strong evidence.

But this research did not find these evidences more convincing, but rather choose to use mathematical application where set notation and matrix equations were used to ascertain the true possible origin of hydrocarbons using certain trace and major elements which actually favour the inorganic origin of petroleum and;

1. The fact that the trace elements found in petroleum ash were of inorganic origin is convincing evidence of abiogenic origin of petroleum.

2. The trace of silicate minerals using matrix equation in petroleum ash is also a convincing evidence of abiogenic origin of petroleum.

3. The existence of methane on other planets of solar, meteors, moons and comets

4. The biogenic explanation fails to explain some of hydrocarbon deposits characteristics.

5. The crude oil distribution of metals fits better with upper serpentinize mantle, primitive and chondrite patterns than the oceanic and the continental crust and never shows any correlation with the sea water.

6. The helium and other noble gas associations with hydrocarbons.

7. Deep hydrocarbon seeps.

8. Some proposed mechanism of abiogenesis formation of petroleum.

9. Diamond within an igneous body as a xenocryst is a characteristic mantle composition. 10 .

\subsection{STATEMENT OF PROBLEM}

Hydrocarbon ash after rigorous analyses had been found to contain some trace elements and minerals of inorganic origin. Most of these elements and minerals are found to be igneous origin and not shale and clays of sedimentary origin. Most of these hydrocarbons drilled today were proven more effective through sedimentary rock than the igneous rocks, yet it has these trace elements of inorganic origin as well as minerals of igneous rock and the questions were;

1. What is the genesis of these trace elements and minerals of inorganic origin in petroleum ash? 
2. Sedimentary rocks formed far below the temperature at which these trace elements and minerals are formed, why? But with the exception that sedimentary rock is a product of igneous rock.

3. These minerals in question in petroleum ash are formed by solid solution which require moderate to high temperature in which sedimentary rocks do not exhibit why?

4. Why is nickel substituted for magnesium in porphyrins of plant, when substitution takes place only at high temperature. It is known that vanadium and nickel are concentrated in the porphyrins and replace the magnesium in chlorophyll.

In order to resolve these problems, certain trace and major elements were used to ascertain this relationship using

1. Set notation

2. Matrix

\subsection{AIM AND OBJECTIVES OF THE STUDY}

The main aim of this research is the application of mathematical model to appraise and ascertain the true origin of HYDROCARBONS using certain major and trace elements of igneous and sedimentary origin with respect to Set notation and Matrix equations and the objectives used to achieve these were;

1. Petrographic Microscope.

The Basalts collected were observed under thin section using both plane and crossed-polarized light.

2. Induced coupled plasma mass spectrometer for trace element examination

(ICP-MS)

Chemical analysis of Kassa basalt, using ICP-MS indicates that Kassa Basalt contains the following trace element in 1ppm 1000ppm such as Fe, Ti, Co, Cr, Ni, Cu, Mo, Pb, Bi, As, Sn, Va, Mn, Ag .

3. Appraisal of hydrocarbons using certain elements, minerals and rocks with respect to set notation and matrix equation.

\subsection{CONCEPTUAL FRAME WORK}

The concept of this model is the design of the structure of Earth in relation to the Ringwood scheme (1974) as shown in Figure 1. The design model consists of two regimes which show the thin denser oceanic crust and thick less denser continental regime that form the Island arc that produces the tholeiite series and the following deduction are made;

1. Oceanic crust which consists of the basalt and gabbro are converted into amphibolite, a hornblende-plagioclase metamorphic rock and then under pressure gradient undergoes dehydration to form water and eclogite, a dense anhydrous rock of basaltic composition.

2. Continental crust, which forms the Island arc that produces tholeiite series as a result of partial melting of mantle pyrolite with aid of hot water released by dehydration of amphibolite to give rise to the differentiation of hydrous tholeiite magma.

3. The hot water released by dehydration of amphibolite reacts with the mantle gases in the presence of metallic substance as a catalyst to produce hydrocarbons. 
Figure 1: Using Ringwood Scheme to show the Evolution of Volcanic rock and Liberation of Hydrocarbons in Kassa Volcanic Field (KVF)

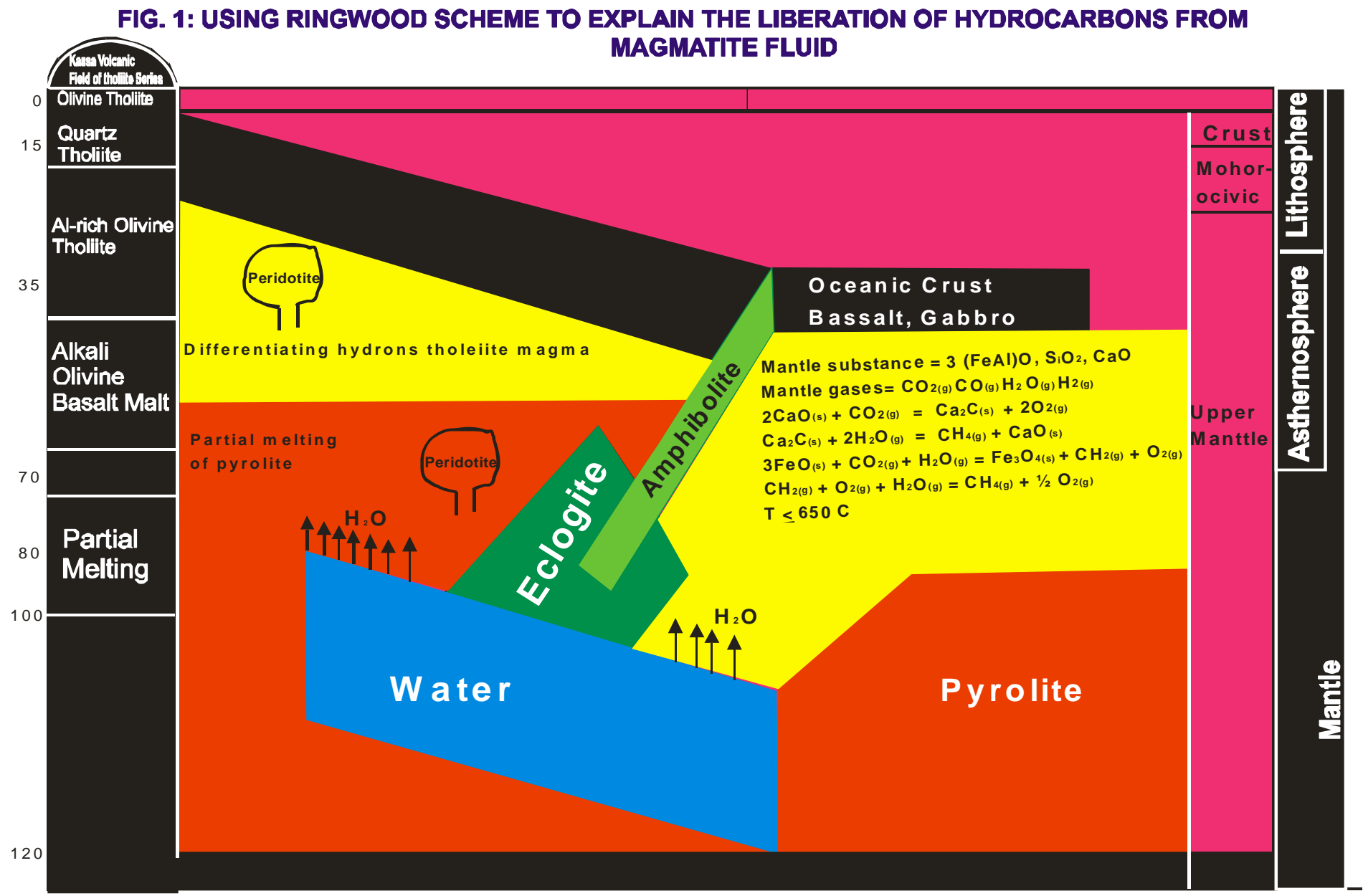

1.4.2 DEFINITION OF TERMS;

MATRIX: Mathematical representation of rectangular array of minerals in rock (ore) arranged in rows and columns with respect to Gibbs free energy

POLYMERIZATION: In the presence of certain inorganic catalysts, at a given control of temperature and pressure, Polymerization in this context is the process involving mathematical addition of hydrogen to hydrocarbon radical (e.g., $\mathrm{CH}_{2}$ ) to produce more saturated alkane of abiogenic origin during crystallization of magma.

"GEOMATHCHEMICAL MODELING as used in this research, is the system of model of computation of numerical values to chemical element in its algebraic form to produce a material of a particular IUPAC nomenclature (name)" e.g. iron ore according to Achuenu, and Komolafe (2021).

\subsection{LITERATURE REVIEW $2.1 \quad$ INTRODUCTION}

Krumbein and Grayhill (1965) have distinguished three types of models in geology: (1) scale-models; (2) conceptual models; and (3) mathematical models. Traditionally, geologists have been concerned with scale-models and conceptual models mainly.

Examples of scale-models are the geological map and cross-sections where the spatial variability of attributes is represented at a reduced scale for topographic surface and vertical planes, respectively. Geological processes also can be represented by scale-models. A classic discussion of this subject was given by Hubbert (1937). Conceptual models are mental images of variables and constants. They are statistical or deterministic depending on whether one or more random variables are 
used in the equation or systems of equations to express uncertainty. Mathematical equations generally can be represented geometrically by curves or surfaces.

The approach of mathematical modeling to abiogenic oil becomes very necessary to appraise the true origin of petroleum hydrocarbons, either it is organic (biogenic) or inorganic (Abiogenic) origin using both major and minor elements which is accomplished by matrix and set rotation method.

Modeling is a process of representing a real world object or phenomenon as a set of mathematical equations, that is process of representing three dimensional objects especially in computer, (Ford, 2009).

The origin of petroleum is a matter of debate since its discovery (Levorsen, 1967). The chief support for theories of inorganic (abiogenic) origin lies in the fact that in laboratory the hydrocarbons methane and benzene have repeatedly been made from inorganic sources. Many scientists believe petroleum originated with decay of primordial biological matter (Robb, 1863). Recent suggest, however that organic molecules may have been included as earth formed by accretion of interstellar materials. Analysis of asteroids and comets has shown they contain a significant amount and variety of organic compound. Methane and other hydrocarbons are found in the atmosphere of Jupiter, Saturn and Uranus.

Wohler (1862) discovered calcium carbid by heating carbon with an alloy of zinc and calcium. He then synthesized acethylene by allowing the calcium carbid to react with water. It is theoretically possible to synthesize anything using reactions of alkyne to form carbon-carbon bonds and to prepare other functional groups, thus Wohler's discovering of calcium carbide gives us a link from inorganic (abiogenic) material to all of organic synthesis. Mendeleev (1877-1902) proposed that metallic carbides deep within the earth reacted with water in hydrothermal fluids to produce acetylene. Porfirev (1974) reviewed the occurrence of oil in the igneous rocks. Studies carried out by several Russian scientists reviewed the association of petroleum hydrocarbons with hydrothermal system.

Gaseous homologs of methane and aromatic and naphthenic oils occur in the fumaroles and injecta of many regions, particularly near mud pots or moderately hot sulphide and carbondioxide type commonly deposite some bituminous material. A remarkable coincidence was pointed out between the major mud volcano regions of the world and the oil producing areas such as Persian Gulf, Caspian Sea, Indonesia and Venezuela. Gaters on the ocean floor have been reported from several areas such as Andriatic, North Sea, Gulf of Mexico South of China Sea and Baltic (Samar Abbas, 1996). Gold (1879),the principal hydrocarbons invoked outgassing from the upper mantle via earthquake activity. According to him, large volumes of methane along with carbondioxide, hydrogen sulphide and traces of noble gases are being degassed from the mantle. They subsequently migrate up through the major fault to be trapped in sedimentary basins or to be dissipated at the earth surface. Examples of such petroleum feeders include flinking faults of the Suez, Rhine, Baikal and Burguzin grabens. Based on the association of gas - oil deposits in the fractured crust/technically active region in the bay of Bengal, particularly in the Andaman sea, (Paropkari, 2008) affirmed their origin to abiogenic at least to partial extent.

Petroleum is defined as any mixture of hydrocarbons that can be recovered from a drill pupe (Sephton A. and Hazen, M. 2013). It occurs in form of oil and which has mainly a chemical composition of hydrocarbons of various carbon chains.

Abiogenesis (inorganic) origin of petroleum is an oldest theory which suggests that petroleum comes from the underneath part of the mantle very long time ago before the existence of life on earth (Mendeleev 1877). Abraham Gottleb Werner and supporters of Neptunism in the 18thh century considered Basaltic sills as solidified oils or bitumen. While these concepts proved not solid, the primary idea of an association between petroleum and magmatism has then persisted as Alexander (1804) proposed an inorganic (abiogenic) hypothesis for petroleum formation after he saw petroleum spring Venezuela. He is quoted as saying in 1804, "the petroleum is the product of distillation from great depth and issues from the primitive rocks beneath which the forces of all volcanic action lie, as it is said above other prominent advocates of abiogenic hypothesis including Mendeleev (1877) and Berthelot (1907). The Soviet Russian geologists, Mikolia, Alexandrovitch and Kudryavtsev (1959) also proposed to modern abiotic hypothesis of petroleum on the basis of his analysis of the Athabasca oil sands in Alberta, Canada, he concluded by the existence of 'source of rocks' that could form the enormous volume of hydrocarbons and as consequence he offered abiotic deep petroleum as the most admirable explanations. Others who continued Kudryavtsev's work are Emmanuel Chekalink, Kroptkin, Georg, Vladiimir, Portfirev, Vladilen, Krayashkin, etc. In $21^{\text {st }}$ Century, the most prominent supporter of the Astronomer Thomas and Kenny. Russain Chemist and Mineroloogist, Mendeleev and Scientific of Epoch have had a great influence supporting the hypothesis. "They proposed that abiogenic methane affects a cosmic organic inheritance that is subsequently released by the mantle and migrates to the surface utilizing weakness in the crust such as plate (Sephton and Hazen, 2013). Recently in 20thh Century, members of the so called 'Russian-Ukrainian school' supported the hypothesis by stating that generated methane polymerizes into higher molecular weight hydrocarbons which result to petroleum deposits, the fact which is also persuade by 
finding increased abundance of methane gas in the depth of petroleum basin (Sephton and Hazen 2013). The tenets supporting abiogenic origin of petroleum are in the following ways:

- The existence of methane on other planets of solar, meteors, moons and comets

- The biogenic explanation fails to explain some of hydrocarbon deposits characteristics.

- The crude oil distribution of metals fits better with upper serpentinize mantle, primitive and chondrite patterns than the oceanic and the continental crust and never shows any correlation with the sea water.

- The helium and other noble gas associations with hydrocarbons.

- $\quad$ Deep hydrocarbon seeps.

- Some proposed mechanism of abiogenesis formation of petroleum.

\subsection{THEORETICAL DEVELOPEMENT}

The appraisal of the origin of petroleum using mathematically modeling approach is based on assumptions that;

1. The transformation of kerogen from shale and clays to petroleum hydrocarbons is organic and is as a result of breaking down of complex organic substance such as protein, carbohydrate etc. into simpler hydrocarbons in the presence of organic catalyst during digenesis. This occurs during deposition of sediment which consolidates to form sedimentary rock

2. Liberation of hydrocarbons from hydrothermal fluid or during dehydration of amphibolite, a hornblende- plagioclase metamorphic rock in the mantle before reaching the depth of $80-100 \mathrm{~km}$ beneath the Earth crust, a process that leads to fractionation of magma from partial melting of mantle pyrolite aided by hot water released by dehydration of amphibolite at the depth of 80 to $100 \mathrm{~km}$ or other hydrous minerals such as serpentinite at the depth of $100 \mathrm{~km}$ to $300 \mathrm{~km}$. This fractionation of the melt during ascent leads to production of tholeiite series of Island arc

\section{1: Fractionation of Tholeiite series of Island arc}

Examination of island arc as shown in Figure 1, indicates in a general way that the first stage of volcanism is often of the tholeiite trend with Basalts and Basaltic Andesites predominating, continued by Lavas having the Calcalkaline trend with Andesite dominant. In still later stages, alkali or shoshonitic lavas are produced. Rocks of the shoshonite series are hypersthenenormative, contain $6.5-7.0 \%$ total alkalies by weight, and have a $\mathrm{K}_{2} \mathrm{O} / \mathrm{Na}_{2} \mathrm{O}$ ratio greater than 1 . Silica is relatively high (50$54 \%$ ). Granites by contrast contain about $8-9 \%$ alkalies and more than $70 \%$ of $\mathrm{SiO}_{2}$

Ringwood (1974) has suggested that the formation of these volcanic rocks is controlled by fractionation processes involving mantle pyrolite, as well as amphibole rich and high pressure metamorphic rocks. The proposed mechanism calls for the presence of water in the subduction zone. This could be furnished by hydrated metamorphic minerals in the subducting oceanic plate, serpentinite, spilitic Basalts and possible hydrated sedimentary material derived from the ocean floor. At various depths these minerals are decomposed, releasing water $\left(\mathrm{H}_{2} \mathrm{O}\right)$ which in turn promotes melting in the hanging wall mantle and within the subdcuting slab as shown in figure 1.

Ringwood's Scheme (1974) as shown in figure 1 suggests that the oceanic basaltic crust is largely converted to amphibolite, a hornblende - plagioclase metamorphic rock, before reaching a depth of about $80-100 \mathrm{~km}$. Here, the amphibole has reached its stability limit mainly due to rise in temperature. The amphibole dehydrates, leaving behind an eclogite, a dense anhydrous rock having the composition of basalt. The released water rises into the hanging wall, causing partial melting of mantle peridotite (pyrolite) and diapiric rise. Fractionation during ascent results in the production of the island arc tholeiite series. The assemblages of tholeiite series include the following;

1. Basalt and basaltic andesite.

2. Intermediate composition.

3. Silicic composition.

The following fractionation and crystallization during ascent occur at the depth of about 15 to $80 \mathrm{~km}$ as shown in Figure 1 and are stated bellow; 
1. An olivine tholeiite melt separated from the pyrolite host at $35-70 \mathrm{~km}$ could rise directly to the surface with no fractionation and crystallize completely to yield olivine tholeiite.

2. It could partially crystallize at the $35-70 \mathrm{~km}$ level to produce alkali-olivine basalt melt or with still more fractionation, an olivine basanit melt.

3. Another possibility is that the original olivine tholeiite melt (which is low in $\mathrm{Al}_{2} \mathrm{O}_{3}$ ) could fractionate during the ascent to the $15-35 \mathrm{~km}$ level and produce an Al-rich olivine tholeiite melt.

4. Still another possibility is that the original olivine tholeiite could fractionate at levels above $15 \mathrm{~km}$, where crystal segregation would yield quatz tholeiite.

\section{0: METHODOLOGY}

The procedures involved the following;

1. Thin sectioning of the rocks, using petrologic microscope under plane and cross-polarised light, and detailed below were the observed minerals and rocks.

(a) Olivine Alkaline Basalt

As shown in Table 2, olivine Alkaline Basalt contains no quarts, olivine $>50 \%$ with single pyroxene e.g. Augit with no other pyroxene. The accessory minerals include magnetite and ilmenite, Basic plagiodase also present.

(b) Tholeiite Basalt

Tholeiite basalt contains no quartz, olivine $>5 \%$, two pyroxenes, augite and orthopyroxene, presence of basic plagioclase. The accessary minerals include magnetite as shown in Table 2.

(c) Olivine Basalt

Olivine Basalt contains no quartz, olivine $>5 \%$, single pyroxene, augite, the presence of basic plagioclase. The accessory mineral includes magnetite.

(d) Olivine Alkali Basalt

Alkali Olivine Basalt contains no quartz, olivine $>50 \%$, single pyroxene such as augite, presence of basic plagioclase. The accessory minerals include magnetite.

3. Induced coupled plasma mass spectrometer trace element examination (ICP-MS)

Chemical analysis of Kassa, using ICP-MS indicates that Kassa Basalt contains the following trace element in 1ppm - 1000ppm such as Fe, Ti, Co, Cr, Ni, Cu, Mo, pb, Bi, As, Sn, Va, Mn, Ag, etc. as shown in Table 3.

4. Petroleum Ash.

Inorganic material may be observed in the ash. The ash from 113 pools on West Virginia varied from 0.04 to $400 \mathrm{ppm}$ of ash, but most of the values ranged between 1 and 10ppm. This data is obtained from Geology of petroleum, by Levorsen second edition CBS, page 190. The elements that have been identified in crude-oil ash include silicon, iron, aluminum, calcium, magnesium, copper, lead, tin, arsenic, antimony, zinc, silver nickel, chromium,titanium molybdenum and vanadium. It is known that vanadium and nickel are concentrated in the porphyrins and replace the magnesium in chlorophyll.

5. Trace elements in plant and animal

The elements that have identified in plant and animal matter include nitrogen, phosphorus, potassium, sulphur, calcium, magnesium and sodium, Boron, iron, manganese, copper, zinc, Molybdenum, chromium, cobalt, selenium and iodine.

\subsection{DISCUSSION OF RESULTS AND PESENTATION OF DATA}

\subsection{INTRODUCTION}

Based on the chemical analyses and the examination under thin section, basalts in KASSA VOLCANIC FIELD (KVF) are classified into alkaline, olivine basalt magma type and tholeiite magma type 
Olivine Basalt Magma Type: The essential minerals are olivine, augite, basic plagioclase, and iron ore. The pyroxene is a diopside or basaltic augite often a titaniferous variety.

Tholeiite Basalt Magma Type: The essential minerals are pyroxene, basic plagioclase and iron ore. Olivine is either completely absent or present in very subordinate amount. The pyroxene belongs typically to the enstatite - augite (pigeonite) series of lime - poor pyroxene.

Yoder and Tilley $(1962$, p.355) comment that in alkali basalts the total alkalis usually exceed $3 \%$. In some siliceous tholeiites the alkalis exceed 3\%, whereas some silica-poor alkali basalts contain less than $3 \%$ total alkalis. Therefore, alkali basalt contains normative olivine and nepheline that is $3 \%<\mathrm{Ne}<5 \%$. $\mathrm{Ne}>5 \%$ is called Basanite. Tholeiite basalt contains less than $5 \%$ modal olivine, tholeiite olivine basalt contains greater than $5 \%$ modal olivine and alkali basalt contains less than $5 \%$ modal olivine. The tholeiite basalt is characterized by the existence of reaction relation between the $\mathrm{Mg}$ olivine and Ca-poor pyroxene, namely orthopyroxene and pegionite (Tilley, 1950, Kuno etal, 1957). Therefore, Mg olivie is usually absent from the ground mass of volcanic rock, where present, it is surrounded by the reaction rims of pegionite provided that the groundmass is reasonably crystalline. Alkali olivine basalt is characterized by the absence of reaction relation between olivine and pyroxene (Tilley, 1950 Kuno etal, 1957), olivine is invariably present in the groundmass.

\subsection{Results and Interpretation}

The rock samples that were collected from Kassa Basalt in Kassa Volcanic Field (KVF) were chemically analyzed using Inductively Coupled Plasma - Mass Spectrometer (ICP-MS) method in Canadian laboratory and the results were presented in table 1,2 and 3

Table1: Partition Coefficientof of Various Trace elements.

\begin{tabular}{|l|l|l|l|c|c|}
\hline Trace Element & $\begin{array}{l}\text { Atomic } \\
\text { radius }\end{array}$ & $\begin{array}{l}\text { Ioniic } \\
\text { Charge }\end{array}$ & $\begin{array}{l}\text { Concentration in } \\
\text { Solid(S) }\end{array}$ & $\begin{array}{l}\text { Concentration in } \\
\text { Liquid(L) }\end{array}$ & $\begin{array}{l}\text { Partition } \\
\text { Coefficient(D) }\end{array}$ \\
\hline Nickel & \multicolumn{2}{|c|}{0,69} & +2 & $\mathbf{1}$ & $\mathbf{4}-\mathbf{1 0}$ \\
\hline \multicolumn{1}{|c|}{ Titanium } & $\mathbf{0 . 6 8}$ & $+\mathbf{4}$ & & & 0.2 \\
\hline Cromium & \multicolumn{1}{|c|}{0.63} & +3 & 1 & 5 & \\
\hline Iron & 0.74 & +2 & & & \\
\hline Robidium & 1.47 & +1 & & 100 & 0.001 \\
\hline Strotium & 1.12 & +2 & 1 & & \\
\hline Zircon & 0.79 & +4 & & & \\
\hline Fluorine & 1.33 & -1 & & & \\
\hline Chlorine & 1.81 & -1 & & & \\
\hline
\end{tabular}

Data presented in Tables 1, 2, 3 and 4 can be analysed and use them to appraise the true origin of petroleum whether it abiogenic or biogenic. The principal minerals in basalt are the basic plagioclase, basic olivine, and basic pyroxene, that is, "CaMg rich minerals". 
International Journal of Advances in Scientific Research and Engineering (ijasre), Volume 7 (6), 2021

Table 2: Majorn Oxides Compositions of KASSA and MIANGO basalts

\begin{tabular}{|c|c|c|c|c|c|c|c|c|c|c|c|}
\hline \multirow{2}{*}{\multicolumn{2}{|c|}{ Mineral }} & \multicolumn{5}{|c|}{ Percentage composition of normative minerals of selected Basalts } & \multicolumn{5}{|c|}{$\begin{array}{l}\text { Percentage Composition of normative } \\
\text { minerals as it is observed from Thin } \\
\text { Section by counting under } \\
\text { Microscope and chemical analysis. }\end{array}$} \\
\hline & & \multirow{2}{*}{$\begin{array}{l}\text { Olivine } \\
\text { basalt } \\
\text { Magma } \\
\text { Type } \\
1\end{array}$} & \multirow{2}{*}{$\begin{array}{l}\text { Tholeiitic } \\
\text { Magma } \\
\text { Type } \\
2 \\
\end{array}$} & \multirow{2}{*}{$\begin{array}{l}\text { Tristan } \\
\text { Olivine basalt, } \\
\text { P.E.Baker et } \\
\text { al, (1964). } \\
\qquad 3\end{array}$} & \multirow{2}{*}{$\begin{array}{l}\text { Hualalai } \\
\text { Alkali basal, } \\
\text { Yolde and } \\
\text { Tilley (1962) } \\
\text { - } \\
4\end{array}$} & \multirow{2}{*}{$\begin{array}{l}\text { Kilauea } \\
\text { Tholeiite, } \\
\text { Yoder and } \\
\text { Tilley, (1962) } \\
5 \\
\end{array}$} & \multicolumn{5}{|c|}{ KASSA } \\
\hline $\begin{array}{l}\text { Geologic } \\
\text { Name }\end{array}$ & $\begin{array}{l}\text { Genetic } \\
\text { Type }\end{array}$ & & & & & & $\begin{array}{l}K I A \\
1\end{array}$ & $\begin{array}{l}K I A \\
2\end{array}$ & KIA3 & KIA4 & KIA5 \\
\hline Quartz & & & 0.0 & 0.0 & 0.0 & 0.3 & 0.0 & 0.0 & 0.0 & 0.0 & 0.0 \\
\hline Olivine & & & 5 & 10.6 & 18.5 & 0.0 & 8.0 & 0.0 & 0.0 & 14.0 & 35 \\
\hline & Augite & & & 29.1 & 20.9 & 22.0 & 17.0 & 1.0 & 4.0 & 11.0 & 10.0 \\
\hline Pyroxene & $\begin{array}{l}\text { Clino- } \\
\text { pyroxene }\end{array}$ & & 51 & 0.0 & 0.0 & 22.4 & 0.0 & 0.0 & 20 & 0.0 & 0.0 \\
\hline \multirow{3}{*}{$\begin{array}{l}\text { Plagioclase } \\
\text { Feldspar }\end{array}$} & $\begin{array}{l}\text { Labradorit } \\
\mathrm{e}\end{array}$ & & 30 & 0.0 & 0.0 & 0.0 & 21.0 & 0.0 & 25 & 22.5 & 12.5 \\
\hline & Bytownite & & & 0.0 & 0.0 & 0.0 & 26 & 1.0 & 26 & 27.5 & 17.5 \\
\hline & Anorthite & & & 20.4 & 23.6 & 26.1 & 0.0 & 0,0 & 0.0 & 0.0 & 0.0 \\
\hline \multirow{2}{*}{$\begin{array}{l}\text { Alkali } \\
\text { Feldspar }\end{array}$} & Albite & & & 3.2 & 20,0 & 21.0 & 0.0 & 0.0 & 0.0 & 0.0 & 0.0 \\
\hline & Orthoclase & & & 12.2 & 5.3 & 2.2 & 0.0 & 0.0 & 0.0 & 0.0 & 0.0 \\
\hline \multirow[b]{2}{*}{ Opaque } & Magnetite & & 9 & 4.1 & 4.5 & 1.9 & 7.0 & & 25.0 & 25.0 & 25.0 \\
\hline & Ilmenite & & & 7.9 & 4.3 & 3.0 & 0.0 & 0.0 & 0.0 & 0.0 & 0.0 \\
\hline Feldsparthoid & Nepheline & & & 11.1 & 2.2 & 0.0 & 0.0 & 0.0 & 0.0 & 0.0 & 0.0 \\
\hline Rest & & & 5 & 0.0 & $0 . .1$ & 0.1 & +21 & +97 & 0.0 & 0.0 & 0.0 \\
\hline Apatite & & & & 1.4 & 0.7 & 0.3 & 0.0 & 0,0 & 0.0 & 0.0 & 0.0 \\
\hline
\end{tabular}


International Journal of Advances in Scientific Research and Engineering (ijasre), Volume 7 (6), 2021

Table 3: Chemical analysis of Kassa using ICPMS

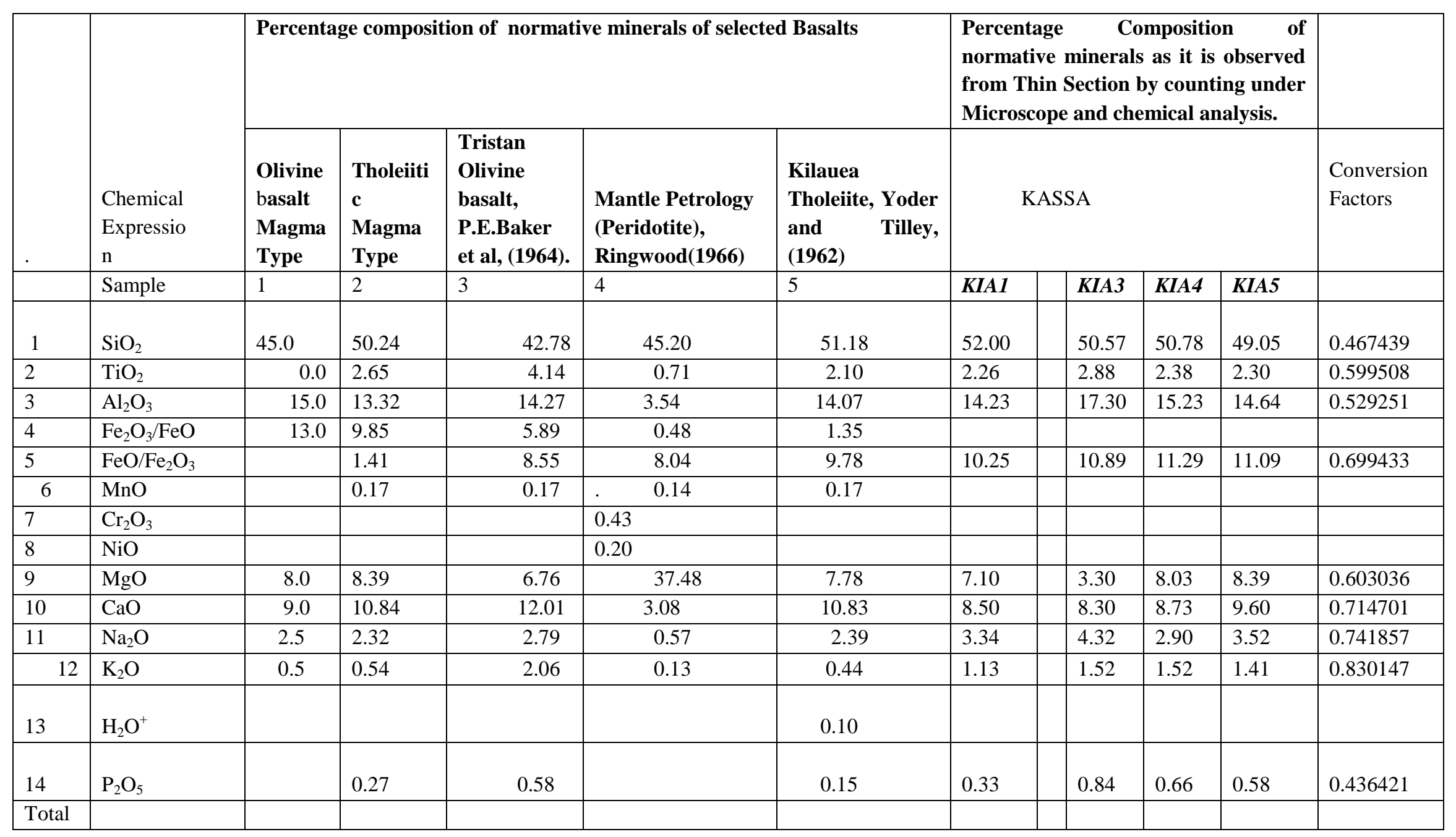


International Journal of Advances in Scientific Research and Engineering (ijasre), Volume 7 (6), 2021

Table 4: Typical Partition Coefficient of Trace Elements between Crystals and Liquid in KASSA Basalts

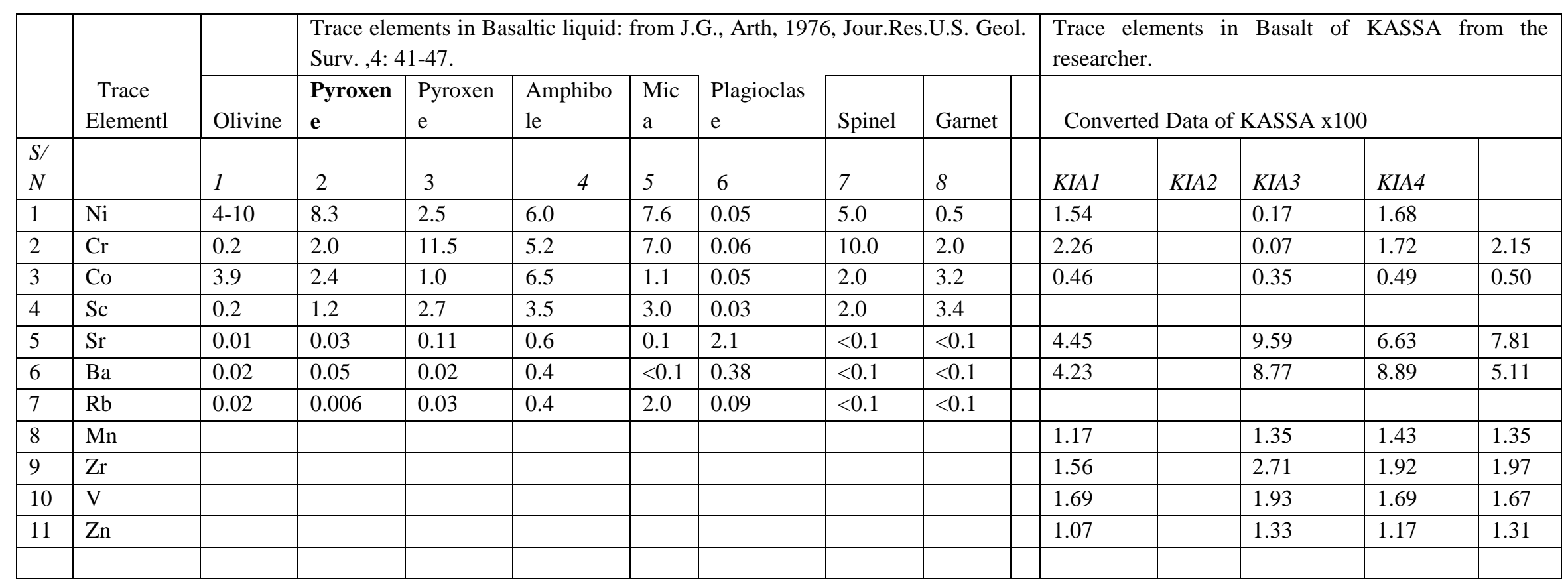

\section{EXPLANATION OF COLUMN HEADINGS}

KIA1: Alkaline Olivine basalt, Kassa, Barkinladi, plateau state.

KIA2: Volcanic Tuff, Kassa, Barkinladi, Plateau state.

KIA3: Tholeiite basalt, Kassa, Barkinladi, Plateau state.

KIA4: Olivine basalt, Kassa, Barkinladi, Plateau state.

KIA5: Alkaline Olivine basalt, Kassa, Barkinladi, Plateau state. 


\section{International Journal of WASRE Advances in Scientific Research and Engineering (ijasre) \\ DOI: $\underline{\text { 10.31695/IJASRE.2021.34028 }}$ \\ E-ISSN : 2454-8006 \\ Volume 7 (6) 2021 \\ June - 2021}

\section{3: Fractionation of Volcanic rock in KASSA VOLCANIC FIELD (KVF) and Probability of Abiogenic Hydrocarbons during}

Evolution

Fractionation of Volcanic rock in KASSA VOLCANIC FIELD (KVF) and probability of finding hydrocarbons (Abiogenic) during evolution of Volcanic rock in KASSA VOLCANIC FIELD (KVF) of Jos Plateau state can be related to the formation of island arcs as explained by Ringwood Scheme (1974) in figure 1.

Samples of volcanic rock were taken at random in KASSA VOLCANIC FIELD (KVF) and examination of these samples as shown in table 2, 3 and 4 indicates in a general way that the first stage of volcanism is often of the tholeiite trend with Basalts and Basaltic Andesites predominating. Ringwood (1974) as explained initially suggested that the formation of these volcanic rocks is controlled by fractionation processes involving mantle pyrolite, as well as amphibole rich and high pressure metamorphic rocks. The proposed mechanism calls for the presence of water in the subduction zone. This could be furnished by hydrated metamorphic minerals in the subducting oceanic plate, serpentinite, spilitic Basalts and possible hydrated sedimentary material derived from the ocean floor. At various depths these minerals are decomposed, releasing water $\left(\mathrm{H}_{2} \mathrm{O}\right)$ which in turn promotes melting in the hanging wall mantle and within the subdcuting slab as shown in figure 1 as previously explained.

The early phase of Volcanic rock in KASSA VOLCANIC FIELD (KVF) is development involving dehydration of amphibolite which leads to the introduction of water into overlying rocks and results in the formation of tholeiite magma series using Ringwood Scheme (1974) as shown in figure 1. The fractionation during ascent results in the formation of tholeiite series of Volcanic rock in Kassa Volcanic Field (KVF) and probability of evolution of hydrocarbons as shown in figure 2 and the Volcanic rocks are;

1. Volcanic Tuff

2. Olivine basalt

3. Tholeiite basalt

4. Alkaline olivine basalt

\subsection{1: Chemical Reaction at the Depth of About $80-100 \mathrm{~km}$ Using Ringwood Scheme as it is related to Kassa Volcanic field $(\mathrm{KVF})$ in Figure 1.}

1. From figure 1, oceanic basaltic crust is converted into amphibolite before reaching the depth of $80-100 \mathrm{~km}$

Basalt: Contains amphibolite with the composition of hornblende-plagioclase metamorphic rock.

Hornblende: $\quad \mathrm{C}_{a}\left(\mathrm{~F}_{e} \mathrm{M}_{\mathrm{g}}\right) 7 \mathrm{~S}_{i 8} \mathrm{O}_{22}(\mathrm{OH})_{2}$

Plagioclase: $\quad \mathrm{C}_{a} \mathrm{Al}_{2} \mathrm{~S}_{\mathrm{i2}} \mathrm{O}_{8}$

2. Dehydration of Amphibolite

Amphibolite dehydrates leaving behind Eclogite and water.

Eclogite: A dense anhydrous rock having the composition of Basalt such as olivine, pyroxene and plagioclase.

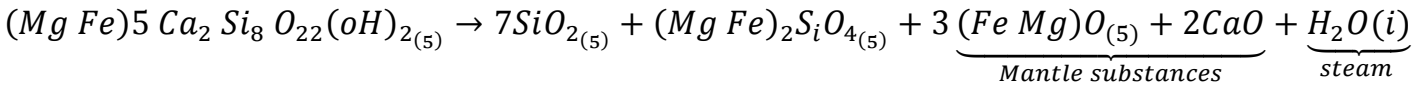

Green et al., (2010) Experimented data shows on the depth of $100 \mathrm{~km}$, temperature is about $977^{\circ} c$ and pressure is $3 G P a$. Both donours of carbon (Carbon itself, $\mathrm{CO}_{2}$ ) and are present in the asthernosphere in sufficient amounts.

The abiogenic synthesis of hydrocarbons can take place in the basic and ultrabasic rocks of the asthernosphere in the presence of $\mathrm{FeO}$, donours/sources of carbon and hydrogen as shown figure 1. The possible reaction of synthesis in this case could present as follows: 
Reduced mantle substance + mantle gasses equals to oxidized mantle substance + hydrocarbons shown in equation (2) below. The released water and mantle substance liberated during dehydration react with $\mathrm{CO}_{2}(g)$

$$
\begin{array}{r}
3 \mathrm{FeO}_{(5)}+\mathrm{CO}_{2_{(g)}}+\mathrm{H}_{2} \mathrm{O}_{(1)} \rightarrow \mathrm{Fe}_{3} \mathrm{O}_{4_{(5)}}+\mathrm{CH}_{2(g)}+\mathrm{O}_{2_{(g)}} \\
\underbrace{3 \mathrm{FeO} \mathrm{O}_{(s)}}_{\text {mantle substance }}+\underbrace{\mathrm{CO}_{2_{(g)}}+\mathrm{H}_{2} \mathrm{O}_{(1)}}_{\text {mantle gases }} \rightarrow \underbrace{\mathrm{Fe}_{3} \mathrm{O}_{4_{(s)}}}_{\text {oxidezed mantle }}+\underbrace{\mathrm{CH}_{2_{(g)}}+\mathrm{O}_{2_{(g)}} \ldots \ldots(2)}_{\text {radicals }}
\end{array}
$$

Mendeleev (1877-1902) proposed that metallic carbides deep within earth reacted with water in the hydrothermal fluids to produced acetylene as shown in the equations ( 3 and 4$)$ below:

- $2 \mathrm{CaO}_{(s)}+2 \mathrm{CO}_{2(g)} \rightarrow 2 \mathrm{CaC}(s)+3 \mathrm{O}_{2(g)}$

- $2 \mathrm{CaC}_{2(s)}+2 \mathrm{H}_{2} \mathrm{O}_{(g)} \rightarrow 2 \mathrm{C}_{2} \mathrm{H}_{2(g)}+2 \mathrm{O}_{2_{(g)}}$

Hydrogenation of alkyne produces saturated hydrocarbons, alkane as shown in (5) below:

- $\mathrm{C}_{2} \mathrm{H}_{2(g)}+2 \mathrm{H}_{2(g)} \rightarrow \mathrm{C}_{2} \mathrm{H}_{6(g)}$

- $\mathrm{C}_{2} \mathrm{H}_{2(g)}+\mathrm{H}_{2} \mathrm{O}_{(g)} \rightarrow \mathrm{CH}_{4(g)}+\mathrm{CO}_{2(g)}$

1. Oceanic basalt: olivine, Pyroxene, Plagioclase
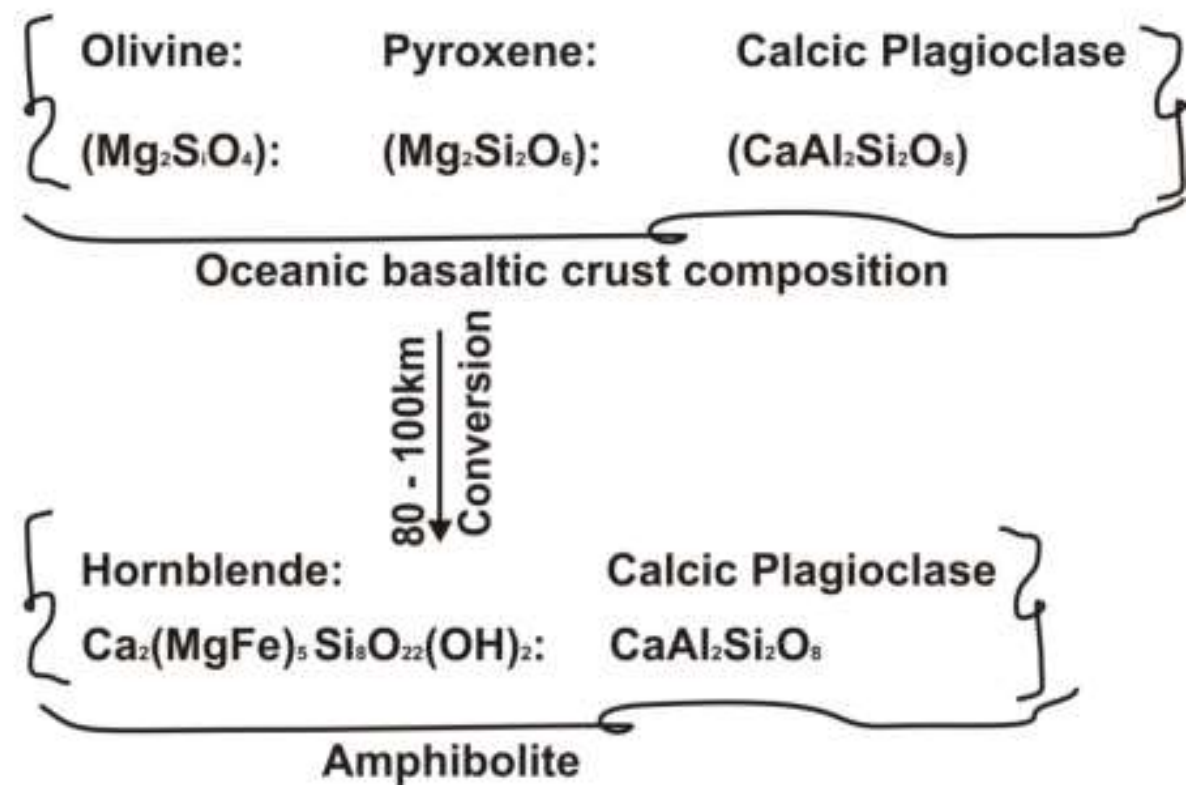
International Journal of Advances in Scientific Research and Engineering (ijasre), Volume 7 (6), 2021

1. Oceanic basalt: olivine, Pyroxene, Plagioclase

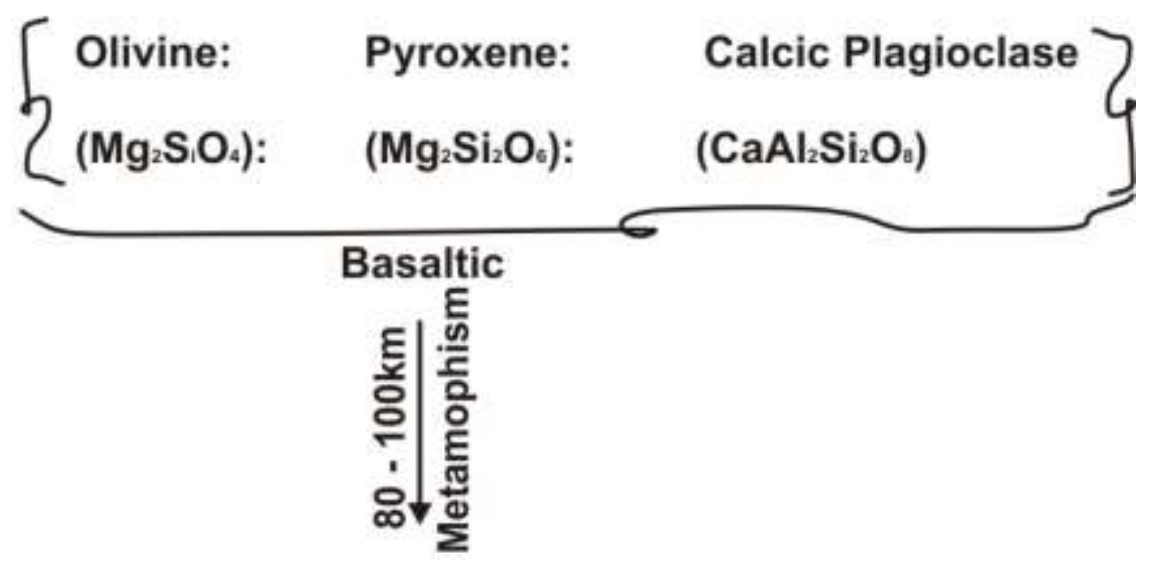

Hornblende: $\quad \mathrm{Ca}_{2}(\mathrm{MgFe})_{5} \mathrm{Si}_{4} \mathrm{O}_{22}(\mathrm{OH})_{2}$

Plagioclase: $\quad \mathrm{CaAl}_{2} \mathrm{Si}_{2} \mathrm{O}_{8}$

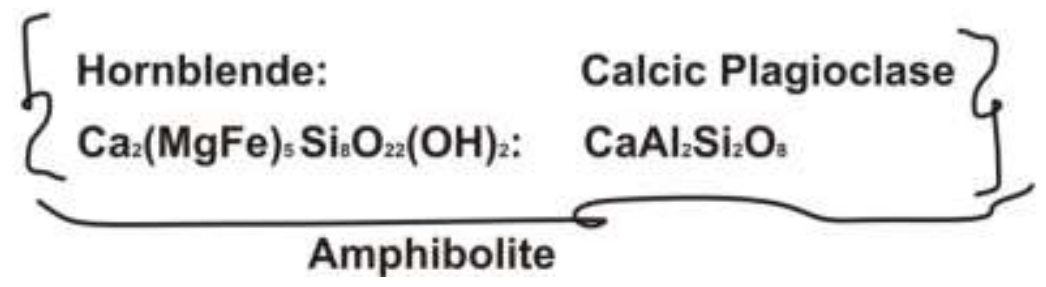

$\mathrm{Ca}_{2}(\mathrm{MgFeAI})_{5} \mathrm{Si}_{8} \mathrm{O}_{22}(\mathrm{OH})_{2}$

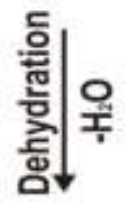

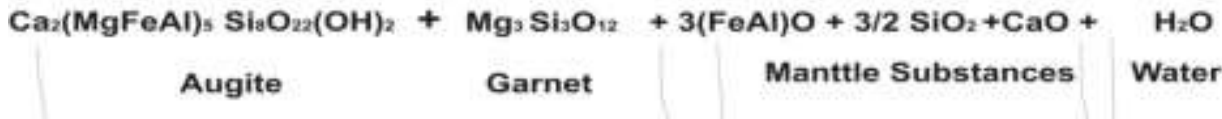

Eclogite

Mantle Substances Released water

Eclogite $=$ Augite + Garnet

Basaltic Composition

Amphibolite $=$ Eclogite + water 
.3.2: Appraisal of Hydrocarbons using certain Major and Trace Elements whether it is an Organic origin or Inorganic origin (Abiogenic)

Miscellaneously, crude oil contains minute amounts of a wide variety of substances, some organic and some inorganic as cited in petroleum geology, A.I.Levorsen second edition, page 190. The material of organic origin, as seen under the microscope, includes such decay-resistant matter as siliceous skeletal tests, petrified wood fragments, spores, spines, cuticles, resins, coal, and lignite fragments, algae, unicellular organisms, spore coats, insect scales, and barbules

The inorganic material may be observed in the ash. The ash from 113 pools in West virginal varies from 0.04 to 400 parts of ash per million, but most of the values ranged between 1 and 10 parts per million. The ash content of the crude oils from Mexico, South America, and the Middle East ranges between 0.003 and 0.72 percent and the certain elements obtained from the ash of these petroleum pools were used to appraise the origin of petroleum. These elements are of inorganic origin and may be observed in the ash of petroleum. The elements include silicon, iron, aluminum, calcium, magnesium, copper, lead, tin, arsenic, antimony, zinc, silver, nickel, chromium molybdenum bismuth and vanadium. Most of the elements are found in sea water and may have been derived from it, as compound in colloidal suspension or as secreted by algae and other marine organisms which may also have provided the material from which the petroleum was formed. It is known that vanadium and nickel are concentrated in the porphyrins and replace the magnesium in chlorophyll, with the result that the vanadium and nickel content of crude oil is frequently several thousand times greater than the concentration in the earth's crust. Vanadium and nickel have been used to correlate crude oils. Clay minerals sometimes come up along with crude oil. These elements can be grouped into major and minor elements. Major elements in petroleum can be appraised using matrix method while minor elements can be appraised using set notation. The major elements include silicon, magnesium, iron and calcium and the remaining elements are minor elements.

Two mathematical methods will be used to ascertain and appraise the origin of petroleum. The methods include

1) The matrix method and

2) The set notation.

i. Matrix Method

The matrix method is used to appraise the major minerals in the petroleum which proves its origin

a) Major Elements in rock. The major elements in basaltic rock include $\mathrm{Si}, \mathrm{Mg}, \mathrm{Ca}, \mathrm{Fe}, \mathrm{Na}$, $\mathrm{K}$, etc., and can be represented in the oxide form such as $\mathrm{SiO}_{2}, \mathrm{MgO}, \mathrm{CaO}, \mathrm{FeO}, \mathrm{NaO}, \mathrm{K}_{2} \mathrm{O}$, etc.

During crystallization, they go into bond formation with $\mathrm{SiO}_{2}$ to produce the following chemical compositions:

- $\mathrm{SiO}_{2} 2 \mathrm{MgO}$

- $\quad \mathrm{SiO}_{2} 2 \mathrm{FeO}$

- $2 \mathrm{SiO}_{2} \mathrm{Al}_{2} \mathrm{O}_{3}$

- $\mathrm{SiO}_{2} \mathrm{Na}_{2} \mathrm{O}$

- $\mathrm{SiO}_{2} \mathrm{~K}_{2} \mathrm{O}$

Using the general formula of mafic and felsic to produce both basic and feldspar

(Achuenu, 2019 unpublished), we have $\left[\left(X_{1}-x Y x\right)\left(A_{4}-y B y\right)\right] 0_{8}$ and $\left(X_{2}-x Y x\right) Z$, such that at $x=0$ and $y=2$, we have,

$$
\begin{aligned}
\left(X_{1} B_{2} A_{2}\right) O_{8} & =0 \\
X_{2} Z & =0
\end{aligned}
$$

When $x=1$ and $y=1$ then

$$
\left(Y_{1} B A_{3}\right) O_{8}=0
$$




$$
Y_{1} Z=0
$$

Where: $\quad \mathrm{X}_{1}=\mathrm{Mg}, \mathrm{Ca}$ for Basic

$$
\begin{aligned}
& \mathrm{Y}_{1}=\mathrm{Fe}, \mathrm{Na} \text { for acidic } \\
& \mathrm{Z}=\mathrm{SiO}_{4}
\end{aligned}
$$

Therefore,

$$
\begin{aligned}
&\left(X_{1} B_{2} A_{2}\right) 0_{8}+\left(Y_{1} B A_{3}\right) 0_{8}=0 \ldots \ldots \ldots \ldots \ldots(11) \\
& X_{2} Z+Y_{2} Z=0 \ldots \ldots \ldots \ldots \ldots \ldots \ldots \ldots \ldots \ldots \\
&(12) \\
&\left(\begin{array}{c}
X_{1} B_{2} A_{2} \\
X_{2} Z
\end{array}\right)+\left(\begin{array}{c}
Y_{1} B A_{3} \\
Y_{2} Z
\end{array}\right)=\left(\begin{array}{c}
X_{1} Y_{1} B_{3} A_{5} \\
X_{2} Y_{2} Z
\end{array}\right)
\end{aligned}
$$

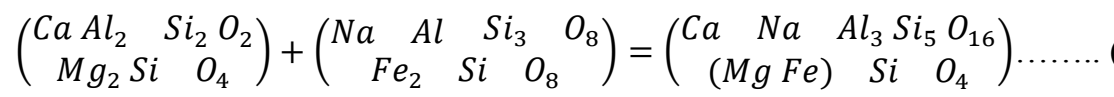

$$
\left(\begin{array}{ll}
0, & 2 \\
0, & 0
\end{array}\right)+\left(\begin{array}{ll}
1, & 1 \\
2, & 0
\end{array}\right)=\left(\begin{array}{ll}
1, & 3 \\
2, & 0
\end{array}\right)
$$

$$
\left(\begin{array}{c}
\text { Anorthite } \\
\text { Fosterite }
\end{array}\right)+\left(\begin{array}{c}
\text { Albite } \\
\text { Fayalite }
\end{array}\right)=\left(\begin{array}{c}
\text { Andesine } \\
\text { olivine }
\end{array}\right)
$$

$$
[\text { Basalt }]+[\text { Rhyolite or Dacite }]=[\text { intermediate }]
$$

b) The major elements in vegetable or animal matter include Nitrogen, phosphorous, potassium, sulphur, calcium, magnesium, and sodium. These elements can also be represented in their oxide form but cannot go into bond-formation with silicon because of absence of the silicon in the plant vegetable matter.

The oxides are:

- $\mathrm{N}_{2} \mathrm{O}$

- $\mathrm{P}_{2} \mathrm{O}_{5}$

- $\mathrm{K}_{2} \mathrm{O}$

- $\mathrm{SO}_{2}$

- $\mathrm{CaO}$

- $\mathrm{MgO}$

- $\mathrm{Na}_{2} \mathrm{O}$

- No silicon minerals formed from plant and animal matter

c) The major elements in petroleum hydrocarbons include silicon, iron, aluminum, calcium and magnesium. The major elements can be represented in the oxide form such as $\mathrm{SiO}_{2}, \mathrm{MgO}, \mathrm{FeO}, \mathrm{CaO}, \mathrm{Na}_{2} \mathrm{O}, \mathrm{K}_{2} \mathrm{O}$, etc. during crystallization, they go into bond formation with $\mathrm{SiO}_{2}$ to produce the following:

- $\mathrm{SiO}_{2} 2 \mathrm{MgO}$

- $\mathrm{SiO}_{2} 2 \mathrm{FeO}$ 
- $\quad 3 / 2 \mathrm{SiO}_{2} \mathrm{Al}_{2} \mathrm{O}_{3}$

- $\quad 1 / 2 \mathrm{SiO}_{2} \mathrm{~K}_{2} \mathrm{O}$

- $\mathrm{SiO}_{2} 2 \mathrm{CaO}$

Using the general formula of mafic and felsic to produce both basic and acidic, we have

$\left[\left(X_{1}-x Y x\right)\left(A_{4}-y B y\right)\right] O_{8} \operatorname{And}\left(X_{2}-x Y x\right) Z$, such that at $x=0$, and $y=2$, we have;

$$
\begin{aligned}
P\left(X_{1} B_{2} A_{2}\right) O_{8} & =0 . \\
P X_{2} Z & =0 .
\end{aligned}
$$

Therefore,

$$
\begin{aligned}
& P\left(\begin{array}{ccc}
X_{1} & B_{2} & A_{2} \\
& X_{2} Z &
\end{array}\right)+\left(\begin{array}{ccc}
Y_{1} B A_{3} \\
Y_{2} Z
\end{array}\right)=\left(\begin{array}{ccc}
X_{1} & Y_{1} & B_{3} A_{5} \\
Y_{2} & Y_{2} & Z
\end{array}\right)
\end{aligned}
$$

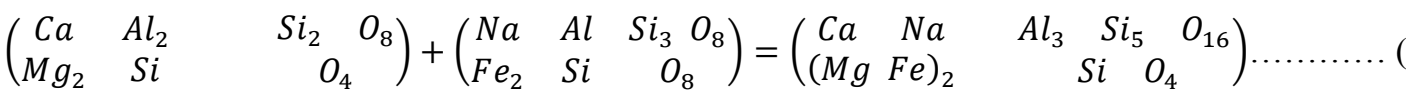

$$
\begin{aligned}
& \left(\begin{array}{ll}
0, & 2 \\
0, & 0
\end{array}\right)+\left(\begin{array}{ll}
1, & 1 \\
2, & 0
\end{array}\right)=\left(\begin{array}{ll}
1, & 3 \\
2, & 0
\end{array}\right) \\
& \left(\begin{array}{c}
\text { Anorthite } \\
\text { Forsterite }
\end{array}\right)+\left(\begin{array}{c}
\text { Albite } \\
\text { Fayalite }
\end{array}\right)=\left(\begin{array}{c}
\text { Andesine } \\
\text { Olivine }
\end{array}\right) \ldots \ldots \ldots \\
& {[\text { Petroleum Ash }]+[\text { Petroleum Ash }]=[\text { Petroleum Ash }]} \\
& \text { from equation (18), putting }[\text { Rhyolite or Daite }]^{\prime} \text { and intermediate }=0 \\
& (\text { Basalt })^{\prime}=0 \\
& (\text { Basalt })=\left(\begin{array}{l}
\text { Anorthite } \\
\text { forsterite }
\end{array}\right) \\
& =\left(\begin{array}{c}
\mathrm{Ca} \mathrm{Al}_{2} \mathrm{Si}_{2} \mathrm{O}_{8} \\
\mathrm{Mg}_{2} \mathrm{SiO}_{4}
\end{array}\right) \\
& (\text { Basalt })=\text { Silicon, calcium, aluminum, magnesium }
\end{aligned}
$$

Comparing equation (18) and (22), we have that;

$$
\begin{gathered}
\text { Basalt }=\text { Petroleum ash } \\
\text { Granite }=\text { Petroleum ash } \\
\text { Intermediate }=\text { Petroleum ash } \\
\text { Since basalt }=\mathrm{Si}, \mathrm{Ca}, \mathrm{Al}, \mathrm{Mg}, \text { then; } \\
\text { Petroleum ash }=\mathrm{Si}, \mathrm{Ca}, \mathrm{Al}, \mathrm{Mg} .
\end{gathered}
$$

Therefore the distributions of major elements in basalt are silicon, calcium, aluminum and magnesium, this means that, the source of $\mathrm{Ca}, \mathrm{Mg}, \mathrm{Si}$ and $\mathrm{Al}$ in petroleum hydrocarbon was from silicate rock such as Basalt and Granite. The oxides of these major elements analyzed from petroleum ash reacted with silica during crystallization of magma to form silicate minerals and these silicate minerals set in matrices to form the silicate rock and this also accounts that there had been substitutions among these elements during crystallization of magma. This confirms that the origin of petroleum was abiogenic. 
ii. Set Notation:

The set theory is used to probe minor element in petroleum which also proves its origin.

a) Using Venn diagram to represent the distribution of major elements in petroleum, Basalt, plant and Animal.

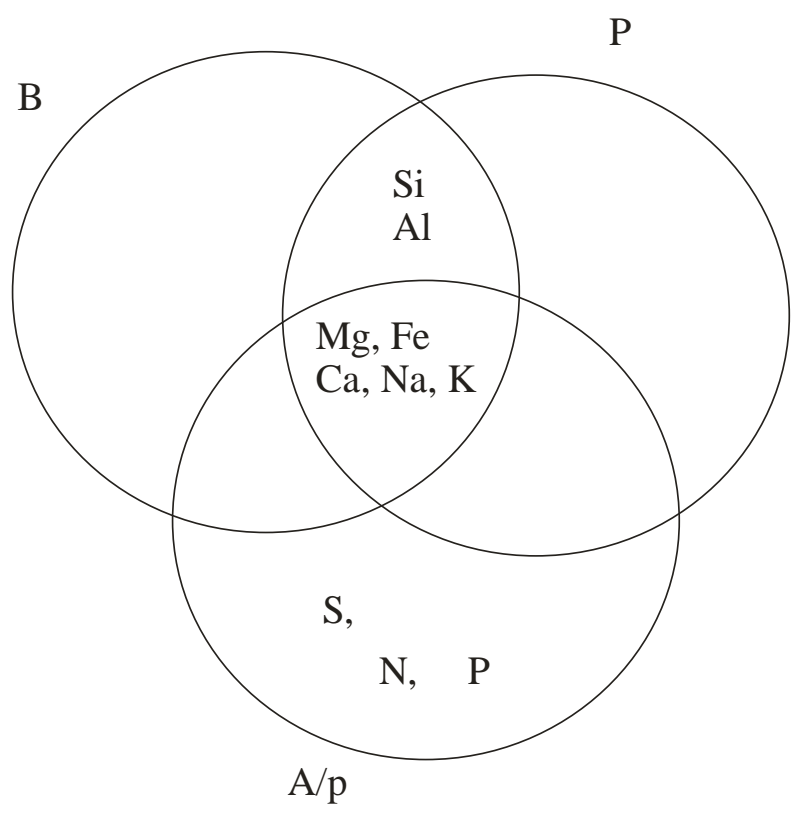

The constituents of petroleum consist of carbon and hydrogen with minor amount of sulphur, nitrogen, phosphorus and oxygen.

To prove that petroleum is also abiogenic and traced to magmatic rocks, the following deductions are made from the Venn diagram.

\section{b) Set Notation for Major Elements in Basalt, Plant and Animal Matter}

If the set of major element in petroleum, Basalts and plant and animal is given as universal set and given as if real elements such as $\mathrm{Si}, \mathrm{Fe}, \mathrm{Mg}, \mathrm{Ca}, \mathrm{Al}, \mathrm{N}, \mathrm{P}, \mathrm{K}, \mathrm{S}, \mathrm{Na}$,

Then:

$$
\begin{gathered}
P=\text { Petroleum } \\
A / P=\text { Plant and Animal } \\
B=\text { Basalt such that } \\
n(p)=S i, F e, M g, C a, A l, N a, K \\
n(A / P)=N, P, K, S, C a, M g, N a, F e, \\
n(B)=S i, F e, M g, C a, A l, N a, K
\end{gathered}
$$

Therefore,

$$
\begin{gathered}
n(P \cap A / P)=K, M g, C a, A l, N a, K \\
n(P \cap B)=S i, F e, M g, C a, A l, N a, K \\
n(P \cap B \cap A / P)=M g, F e, C a, N a, K
\end{gathered}
$$

1. $n(B \cap P)=S i A l$ 


\section{International Journal of Advances in Scientific Research and Engineering (ijasre), Volume 7 (6), 2021}

Therefore, the relationship between Basalt and Petroleum is SiAl. This means silicon and aluminum. This also means that there is a bonding relationship between SiAl and Mafic to produce silicate minerals in petroleum. These silicate minerals include plagioclase, olivine and pyroxene. This indicates the presence of silicate minerals in petroleum hydrocarbons.

2. $n(P \cap A / P)=\{$ empty

Therefore, there is no relationship between petroleum hydrocarbon and with plant and animal matter using petroleum ash. This means that the major elements found in petroleum ash do not conform to the major elements in plant and animal matter

3. $n(B \cap P \cap A / P)=\{M g, F e, C a, N a, K\}$

Therefore, the common elements found among Basalt, petroleum and animal/plant do not represent whether petroleum is of organic or abiogenic. The relationship is not certain because they have common elements.

\subsection{4: Set Notation for Minor or Trace Elements in Petroleum Hydrocarbons, Basalt and Animal/Plant Matter}

The universal set $\in$ is used to represent the set of all real minor or trace elements in petroleum, Basalt and Animal/Plant matter.

$\in=X, F e, A g, C a, P b, S n, A s, S b, A g, N i, C r, M o, V, C o, B a, T i, B i, C d, M n, A s$,

Given that,

$$
n(B)=F e, C a, p b, S n, A s, S b, A g, N i, C r, M o, V, C o, B a, T i, B i, C d, M n, A s, S r
$$

$n(A / P)=C a, p b, F e, M o, C o, M n$

$n(p)=F e, C a, P b, S n, A s, S b, A g, N i, C r, M o, V, C o, B a, T i, B i, C d, M n, A s$

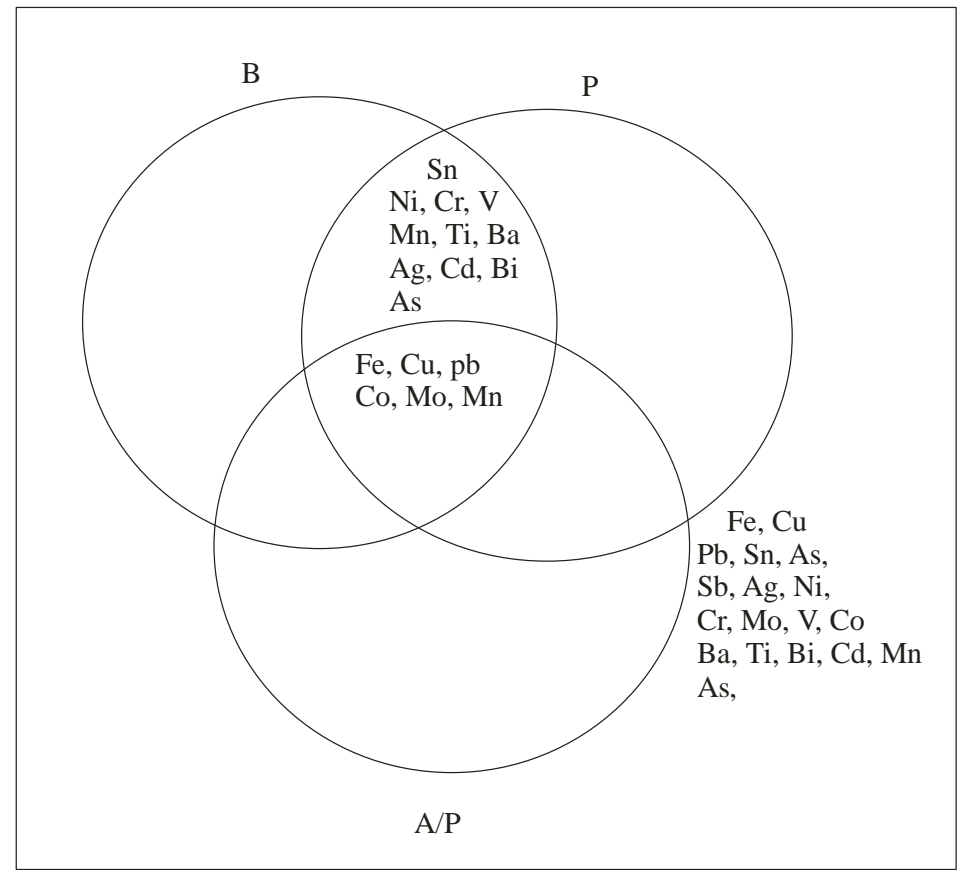

Using the Venn diagram, trace elements are used to ascertain whether petroleum is abiogenic or biogenic and is represented in the set notation below:

1. $n(P \cap B)=[S n, T i, N i, V a, C r, M n, B a, A g C d, B i, A s]$

2. $n(P \cap A / P)=\{\}$ empty

3. $n(P \cap B \cap A / P)=\{F e, C u, p b, C o, M o\}$ 


\section{International Journal of Advances in Scientific Research and Engineering (ijasre), Volume 7 (6), 2021}

4. $n(B \cap A / P)=\{$ empty

$n(P \cap B)=\{S n, T i, N i, V a, C r, M n, A g, C d, B i, A s\}$, indicates the abiogenic origin of petroleum.

Given that $n(P \cap B)=\{S n, T i\}$

$$
=[T i T i]
$$

TiTi Found in both petroleum and Basalt is a convincing evidence of abiogenic origin of petroleum this is because, Titanium and Tin are basically igneous origin (hydrothermal).

Given that $n(P \cap B)=\{N i V a\}$

$$
=\{N i V a\}
$$

Niva Found in both petroleum and Basalt is a convincing evidence of abiogenic origin of petroleum. Niva Is used to correlate petroleum and substitute for magnesium in porphyrin. Niva is not found in plant and Animal matter which affirms the convincing evidence of abiogenic origin petroleum.

$n(P \cap A / P)=\{\quad$ empty, indicates that petroleum is not biogenic origin, because of absence of most important trace elements found in petroleum ash.

\subsection{5: Mathematical Equations for Hydrocarbons (Abiogenic Hydrocarbons)}

Given that the source of carbon is abiogenic and it exists at the depth of about 80-100k in the asthernosphere according to Green et al (1969).

The derivations of abiogenic alkanines are based on charged balanced of constituent's species according to Denbigh (1971) which states that the principle of electroneutrality requires that the ionic species in an electrolyte solution remains charge balanced in a microscopic scale. The electroneutrality condition of balance among the species in solution, according to equation below:

$$
\in Z i M c+\in Z j m j=0
$$

Where $Z i$ and $Z j$ are the ionic charges on the basis and secondary species. It is useful to note, however that electroneutrality as assumed when the components in the basis are charge balanced.

Mathematically, carbon has an ion with a charge of $(+4)$.

$$
\mathrm{C}=-4
$$

Let the hydrogen molecule derived from $\mathrm{H}_{2} \mathrm{O}$ at the depth of about $30-100 \mathrm{~km}$ be $\mathrm{X}$

$$
\begin{aligned}
n C X & =0 \ldots \ldots \ldots \ldots \\
n & =\text { ionic species } \\
n & =4 / 2 \\
X= & (+2) \\
\therefore n(C X) & =\frac{4}{2}(C X) \\
& =2 X_{2} C_{2} \\
& =2 X c \\
2 X & =X_{2}
\end{aligned}
$$




$$
\begin{gathered}
\quad=C_{2} X_{2} \\
=C X_{2} \\
n(C X)=C X_{2} \ldots
\end{gathered}
$$

$\therefore C X_{2}$ Is a radical and unsaturated with a unit residual charge of? -2

With increasing temperature, during fractionation of abiogenic crude oil, the molecule (n) also increases as show in equation below.

$$
\begin{aligned}
\left(\mathrm{CX}_{2}\right)_{\mathrm{n}} & =-2 \ldots \ldots \ldots \ldots(25) \\
\mathrm{n} & =\text { molecular fraction } \\
\mathrm{C}_{\mathrm{n}} \mathrm{X}_{2 \mathrm{n}} & =-2 \\
\mathrm{C}_{\mathrm{n}} \mathrm{H}_{2 \mathrm{n}+2} & =0 \ldots \ldots \ldots \ldots \ldots(26)
\end{aligned}
$$

This equation is used to calculate all the abiogenic alkane groups from the magmatic rock (igneous).

\subsection{6: Polymerization of Alkane from Magmatic or Hydrothermal fluid}

Polymerization is essentially the reverse of cracking, inasmuch as it causes number of small molecules to unite and form larger molecule. It is combining of simple molecules to form complex molecules. In the presence of magnetite $\left(\mathrm{Fe}_{3} \mathrm{O}_{4}\right)$ according to Kolesnikov etal (2009), higher alkane is transformed into the heavier alkanes, so that at a temperature of $627-1227^{\circ} \mathrm{C}$, there is a complete transformation of lighter gas into heavier crude oil at the depth of about $30-100 \mathrm{~km}$ in the reducing environment beneath the earth crust such as taking place in the island arch or volcanic vent of Kassa Volcanic Field (KVF) according to Ringwood Scheme (1977). These are shown in equation below.

Since,

$$
\mathrm{C}_{\mathrm{n}} \mathrm{H}_{2 \mathrm{n}}+2=0
$$

Then at $\mathrm{n}=1$,

$$
\mathrm{C}_{\mathrm{n}} \mathrm{H}_{2 \mathrm{n}}+2=\mathrm{CH}_{4} \text { (methane) }
$$

$4 c \mathrm{H}_{4(g)}+2 \mathrm{fe}_{3} \mathrm{O}_{4} \stackrel{627-1227^{0}}{\longrightarrow} 2 \mathrm{C}_{2} \mathrm{H}_{6(g)}+6 \mathrm{Fe}_{(g)}+2 \mathrm{H}_{2} \mathrm{O}+3 \mathrm{O}_{2}$

Polymerization of abiogenic hydrocarbons is shown below

$$
\begin{array}{r}
4 \mathrm{CH}_{4(g)}+2 \mathrm{fe}_{3} \mathrm{O}_{4_{(5)}} \stackrel{627-1227^{\circ} \mathrm{C}}{\longrightarrow} 2 \mathrm{C}_{2} \mathrm{H}_{6(g)} 6 f e_{(s)}+2 \mathrm{H}_{2} \mathrm{O}_{2}+3 \mathrm{O}_{2} \\
\downarrow \\
\downarrow \\
C_{3} H_{8_{(g)}} \\
\downarrow \\
C_{4} H_{1} 10_{(g)} \\
\downarrow \\
C_{5} H_{12(g)} \\
\downarrow \\
C_{n} H_{2 n+2} \\
\downarrow \\
\\
2 \mathrm{CH}_{4(g)}+\mathrm{Fe}_{3} \mathrm{O}_{4(s)} \stackrel{>1227^{\circ} \mathrm{C} C}{\longrightarrow}+\begin{array}{c}
2 C_{(s)} \\
\text { graphite }
\end{array} \\
\end{array}
$$




\section{International Journal of Advances in Scientific Research and Engineering (ijasre), Volume 7 (6), 2021}

Alternatively, at a temperature higher than $1227^{\circ} \mathrm{C}$, methane dissociates to pure carbon (graphites and molecular hydrogen as shown equation below

$$
\mathrm{CH}_{4(g)} \stackrel{>1227^{0} \mathrm{C}}{\longrightarrow} \mathrm{C}_{(s)}+2 \mathrm{H} 2_{(g)} \ldots \ldots \ldots \ldots
$$

$\therefore$ In the increasing number of hydrogen molecules, carbon atoms also increases with increases temperature at the depth of $80-100 \mathrm{~km}$ as shown below

$$
\therefore \mathrm{CH}_{4(g)} \rightarrow \mathrm{C}_{2} \mathrm{H}_{6(g)} \rightarrow \mathrm{C}_{3} \mathrm{H}_{Z_{(g)}} \rightarrow \mathrm{C}_{4} \mathrm{H}_{10}(g)+\mathrm{H}_{2(g)}
$$

The above arrangement is called Homologous series in which each member differs by $\mathrm{CH}_{2}$ radical and is represented in Table 4 .

\subsection{7: Diamond Xenocryst as Abiogenic oil Indicator}

At a high temperature and pressure, the atoms of carbon (graphite) are held together by a very strong covalent bond to form a three-dimensional lattice that is colorless, transparent solid; sparkles when cut and polished called Diamond. Diamond acts as a xenocyst within an igneous body. Experiments have shown that, crystal of diamond was carried from a great depth under high temperature and pressure to the surface. This happens as result of crystallization during the ascent and diapiric rise. Since mantle consists of carbon from $\mathrm{CO}_{2}$ source as donor of hydrocarbon at the depth of about $100 \mathrm{~km}$, carbon itself at high temperature and pressure bond together to form, a hard, lustrous three dimensional solid that is highly reflective and abrasive called Diamond and brought to the surface along with magma. Ideally, in order to have samples truly representative of mineral assemblage's characteristic of the mantle and lower crust, the xenoliths should be brought rapidly to the surface. Fortunately, the variety of peridotite known as kimberlites contain diamonds, known from laboratory experiments to be more stable only at very high pressure. It is therefore assumed that kimberlite magmas reach the surface very rapidly by an explosive process, and commonly contain xenoliths brought from all levels, those of deep origin are generally able to maintain the high pressure assemblages and phase compositions characteristic of the upper mantle. The most common types of deep-seated xenoliths are peridotite and eclogite.

At high temperature and under the same depth, carbon (iv) oxide from carbon source, reacts with water to produce hydrocarbons. Therefore, since so many scientists believed that diamond comes from the mantle along with the magma called kimberlite magma, then there is a genetic relationship between the formation of diamond and formation of hydrocarbons and therefore the true origin of hydrocarbon can be link to the mantle of the earth which composed mainly of basaltic composition such eclogite, pyrolite, garnet etc.

\subsection{7: The Porphyrin and Optical Activity of Petroleum as Indicators of Petroleum Origin}

The optical activity is one of the properties of petroleum used to trace the true origin of petroleum in this research. Minerals observed in petroleum ash using mathematical approach include Quartz, Olivine, Pyroxene and Feldspars and other accessory minerals such Magnetite and Haematite. Olivine, pyroxene and the iron ores are the opaque minerals and therefore do not reflect even at the thin edge under polarized light, while quartz and the feldspars are transparent minerals and have the ability to rotate the plane of polarization of polarized light.

Porphyrins are formed from red colouring matter of blood (hemin) or from green colouring matter of plant (Chlorophyll). Porphyrins in petroleum occur in form of complex hydrocarbon compounds that oxidize readily. Treibs found the vegetable porphyrins $\left(\mathrm{C}_{32} \mathrm{H}_{36} \mathrm{~N}_{4}\right.$ and, $\left.\mathrm{C}_{32} \mathrm{H}_{36} \mathrm{~N}_{4} \mathrm{COOH}\right)$, derived from chlorophyll, to be more plentiful than the animal porphyrinc $\left(\mathrm{C}_{32} \mathrm{H}_{38} \mathrm{~N}_{4}\right.$ and, $\mathrm{C}_{32} \mathrm{H}_{36} \mathrm{~N}_{4} \mathrm{COOH}$ ), derived from hemin.

Polymerization of alkyne radicals, also produce complex hydrocarbon compounds as shown in equation (32) below;

$$
16 \mathrm{C}_{2} \mathrm{H}_{2(\mathrm{~g})}+2 \mathrm{H}_{2(\mathrm{~g})} \rightarrow \mathrm{C}_{32} \mathrm{H}_{36(\mathrm{~s})}
$$

In the presence of Nitrogen molecule at the depth of $80-100 \mathrm{~km}$, under control condition of temperature, these complex hydrocarbons oxidize to Porphyrins, complex hydrocarbon compounds that occur at a low temperature as shown in equation (33).

$$
\mathrm{C}_{32} \mathrm{H}_{36(\mathrm{~s})}+2 \mathrm{~N}_{2(\mathrm{~g})} \rightarrow \mathrm{C}_{32} \mathrm{H}_{36} \mathrm{~N}_{4(\mathrm{~s})}
$$




\section{International Journal of Advances in Scientific Research and Engineering (ijasre), Volume 7 (6), 2021}

At the depth of $25-100 \mathrm{~km}$, the presence of mantle gases such as water, carbondioxide, and hydrogen cause the complex compound to be oxidized as shown in equation (34)below;

$$
\mathrm{C}_{32} \mathrm{H}_{36(\mathrm{~s})}+\mathrm{CO}_{2(\mathrm{~g})} \rightarrow \mathrm{C}_{32} \mathrm{H}_{35} \mathrm{~N}_{4} \mathrm{COOH}_{(\mathrm{s})} \ldots \ldots . . .(34)
$$

Mathematically, porphyrins, $\mathrm{C}_{32} \mathrm{H}_{36} \mathrm{~N}_{4}$ and, $\mathrm{C}_{32} \mathrm{H}_{36} \mathrm{~N}_{4} \mathrm{COOH}$, are found in appreciable amounts in abiogenic crude oil, of high asphaltic content which suggests later origin of asphaltic content, because polymerization starts from light crude at high temperature to heavier crude at low temperature during evolution of igneous rock from the magmatic melt or hydrothermal fluid.

The colour of abiogenic crude oil depends on the isomorphous ionic substitution among magnesium, iron, vanadium, nickel and chromium as presented in table 2, 3, and 4 during crystallization of magma. If the colour takes the green pigment as found in green colouring matter of plant called chlorophyll, then the porhyrin type is Magnesium porphyrin with chemical formula of, $\mathrm{C}_{32} \mathrm{H}_{36} \mathrm{~N}_{4} \mathrm{Mg}$ attributed by treibs, but if the colour takes the red pigment, as found in red colouring matter of animal (blood) called Haemoglobin, then it is Iron porphyrin with chemical formula of, $\mathrm{C}_{32} \mathrm{H}_{38} \mathrm{~N}_{4} \mathrm{Fe}$ as noted by Treibs. Also isomorhous substitution of magnesium and iron by vanadium and nickel in porhyrins is also possible during crystallization of magma at a regulated temperature.

Based on this analogy, the concept that, the presence of porphyrin, a natural pigment related to chlorophyll and Haemoglobin in crude oil is evidence of its biological origin of pertroleum proposed by biogenic proponent of petroleum is also applicable to abiogenic oil proposed by abiogenic proponent as explained above. Therefore, abiogenic oil can also be found to contain Porphyrins.

Mathematically, certain minerals such as Quartz and Feldspars contained in petroleum ash as analysed using matrix method, have the ability to rotate the plane of polarization of polarize light. This means that the power to the plane of polarization of polarized light is not only the property of biogenic oil, as proposed by biogenic proponent of petroleum but also property of abiogenic oil obtained during evolution of volcanic rocks from the magmatic melt or hydrothermal fluid.

In conclution, it is believed that the optical activity in petroleum is due to the presence of cholesterol $\left(\mathrm{C}_{26} \mathrm{H}_{45} \mathrm{OH}\right)$, which is found in both vegetable and animal matter, but other minerals such as Quartz and Feldspars in petroleum also contribute to the optical activity of petroleum.

\subsection{8: Probability of Biogenic or Abiogenic origin of Hydrocarbons}

Carbon and hydrogen are main components of petroleum hydrocarbon with minor amounts of nitrogen, phosphorus, oxygen and sulphur and are present in living matters such as plant and animal matters as well as hydrothermal and magmatic fluids, therefore, cannot be used to ascertain the origin of petroleum hydrocarbons.

Certain trace elements are used to ascertain this origin and analysis of petroleum ash using induced-coupled plasma and Emission Mass Spectrometer (ICP/EMS) shows this trace elements, therefore the origin of petroleum hydrocarbon becomes a matter of probability.

Using probability theory to affirm the origin of petroleum hydrocarbon based on the available evidences from different data sources. According to probability theory, this states that;

The probability of an event to occur + probability of an event not occur is equal to 1 (one).

Given that the probability of an event to occur $=\mathrm{E}$

The probability of an event not to occur $=\mathrm{E}$

$$
\begin{aligned}
\therefore P(E)+ & P\left(E^{\prime}\right)=1 \ldots \ldots \ldots \ldots \\
P(E) & =1-P\left(E^{\prime}\right)
\end{aligned}
$$

$\therefore$ Let the probability of an event to occur equal to probability of petroleum to occur in hydrothermal fluid (igneous origin).

The probability of an event not to occur equals to the probability of petroleum not occurs in hydrothermal fluid (igneous origin).

Given that $E=P$ and $E^{\prime}=P^{\prime}$ 
International Journal of Advances in Scientific Research and Engineering (ijasre), Volume 7 (6), 2021

$$
\begin{array}{r}
P=\text { petroleum } \\
\therefore P(P)+P\left(P^{\prime}\right)=1 \ldots \ldots \ldots \ldots \ldots(34)
\end{array}
$$

The probability of petroleum to occur in hydrothermal fluid is the probability that all trace elements in petroleum ash are included in hydrothermal fluid (igneous origin).

$$
\begin{array}{r}
\therefore n(P \cap B)=\text { all included trace elements } \\
=F e, C u, p b, S n, A s, S b, A g, N i, C r, M o, V, C o, B a, T i, C a, M u, A s . \\
n(P \cap B)=P(P) \ldots \ldots \ldots \ldots \text { (35) }
\end{array}
$$

The probability of petroleum not to occur in hydrothermal fluid is the probability that all trace elements in petroleum hydrocarbons are not included in plane and animal matter.

$$
\begin{aligned}
\therefore n(P \cap A / P) & =P(P)\{\} \\
n(P \cap A / P) & =P\left(P^{\prime}\right)^{0} \ldots . .(36) \\
\therefore P(P) & =F e, C u, p b, S n, A s, S b, A g, N i, C r, M o, V, C o, B a, T i, C d, M n, A s \\
P\left(P^{\prime}\right) & =0 \\
P(P)+ & P\left(P^{\prime}\right)=1 \\
P(P)+0 & =1 \\
P(P) & =1
\end{aligned}
$$

$\therefore P(P)=1$ Means that the probability of finding hydrocarbons is convincing evidence that, petroleum hydrocarbons are of abiogenic origin (igneous origin). The abiogenic origin of petroleum hydrocarbon has three possibilities in this research. These possibilities include;

- SiAl: Major elements

- TiTi: Trace elements

- $\quad$ NiVa: Trace elements

These three possibilities of finding the petroleum hydrocarbon in hydrothermal fluid (igneous origin) are unfortunately not found in plant and animal matters (organic origin).

$$
\begin{aligned}
& \therefore P(P)=1 \\
& P(P)=[\{\text { SiAl }\},\{\text { TiTi }\},\{\text { NiVa }\}] . \\
& n(P)=3(\text { three possibilities })
\end{aligned}
$$

Using certain trace and major elements to trace the origin of petroleum, three possibilities have been postulated to appraise the origin of petroleum from magmatic or hydrothermal fluid as shown in equation (38).

Also the presence of diamond as a xenocryst within igneous intrusion is one of indicators used to trace the origin of petroleum from magmatic or hydrothermal fluid. 


\section{0: SHORTCOMINGS}

Despite the convincing evidences from different authors, especially those of Gold, Mendeleev, Kenny, about the hydrothermal (igneous), origin of petroleum (abiogenic), the organic origin of petroleum is still very much favored due to the following reasons:

1. The ability of petroleum to possess, optical activity the power to rotate the plane of polarization of polarized light which occurs only in organic material and is caused by the presence of a cholesterin - like substance. Cholesterin (cholesterol), which is alcohol with formula $\mathrm{C}_{26} \mathrm{H}_{45} \mathrm{OH}$ is found in both vegetable and animal matter and cannot be synthesis inorganically.

2. The drilling of oil and gas through igneous rock has not been commercially proven, but those of organic origin have been commercially proven. This means that commercial production of oil and gas in igneous rock has not made any breakthrough because of ineffectiveness of drilling - hardwork.

\section{0: STATE OF CURRENT RESEARCH}

The weight of evidence currently shows that petroleum is derived from ancient biomas. However, it still has to be established alternative theories of petroleum formation cannot be dismissed.

A 2006 review article by Geoffrey Glasby presented arguments against the abiogenic the other hand several studies demonstrated that hydrocarbons heavier than methane can be produced in abiogenic process.

\section{0: EMPIRICAL EVIDENCE OF ABIOGENIC OIL}

The soviet school saw evidence of their hypothesis in the fact that some oil reservoirs exist in non-sedimentary rock such as granite, metamorphic or porous volcanic rock. However, opponents noted that non-sedimentary rocks served as reservoir for biologically originated oil expelled from nearby sedimentary source rock through common migration or remigration mechanism.

The following observations have been commonly used to argue for the abiogenic hypothesis; however, each observation of actual petroleum can also be fully explained by biotic origin.

\section{Lost city hydrothermal vent Field}

The lost city hydrothermal field was determined to have abiogenic hydrocarbon production. Proskurowski et al wrote "Radiocarbon evidence rules out sea water bicarboneate as the carbon for FTT reaction, suggesting that a mantle derived inorganic carbon source is leached from the host rocks. Our findings illustrate the abiogenic synthesis of hydrocarbons from ultramafic rocks, water and moderate amounts of heat.

\section{The Siljan Ring Crater}

The Siljan Ring Meteorite crater, Sweden was proposed by Thomas Gold as the most like place to test the hypothesis because it was one of the few places in the world where granite basement was cracked sufficiently (by meteorite impact to allow oil to seep up from the mantle.

In 1986-1990, the Gravberg-1 borehole was drilled through the deepest rock in the Siljan Ring in which proponents had hoped to find hydrocarbon reservoirs. It stopped at the depth of 6,800 metres $(22,300 \mathrm{ft})$ due to drilling problems, after private inve stors spent $\$ 40$ million. Some eighty barrels of magnetite past and hydrocarbon-bearing sludge were recovered from the well, Gold maintained that the hydrocarbons were chemically different from and not derived those added to the borehole, but analysis showed that the hydrocarbons were derived from the diesel fuel-based drilling fluid used in the drilling. This well also sampled over 13,000 $\mathrm{ft}(4$, $000 \mathrm{~m}$ ) of methane-bearing inclusions. 


\section{0: SUMMARY}

The probability that the origin of petroleum hydrocarbons is abiogenic (inorganic source) is summarized in the following ways:

1. The production of tholeiite series in the island arc according to Ringwood (1977), might lead to the evolution of hydrocarbons at the depth of about $80-100 \mathrm{~km}$ with temperature of about $977^{\circ} \mathrm{c}\left(625-1500^{\circ} \mathrm{c}\right)$ and pressure of $25 \mathrm{k}$ bar.

2. Water released during the production of tholeiite series react with carbon as carbon dioxide in the asthenosphere to produce methane, according to Mendeleev and is shown in equation below

$$
\mathrm{H}_{2} \mathrm{O}+\mathrm{CO}_{2} \rightarrow \mathrm{CH}_{4}+\mathrm{H}_{2} \mathrm{O}+\mathrm{CO}_{2}+\mathrm{feO} \rightarrow \mathrm{CH}_{4}+\mathrm{fe}_{3} \mathrm{O}_{4}
$$

3. The duplex theory combining features of both inorganic and organics theories may be the final choice, according Robinson (1963) which indicates that the probability of finding hydrocarbon in both organic and inorganic origin is unitary.

This means

$$
\begin{aligned}
\therefore P(P)=\text { inorganic origin }(\text { abiogenic }) \\
\therefore P\left(P^{\prime}\right)=\text { organic origin }(\text { biogenic })
\end{aligned}
$$

4. $P\left(P^{\prime}\right)=1-P\left(P^{\prime}\right)$

Given that $P\left(P^{\prime}\right)=0$, means that, the trace elements found in petroleum ash are not include in biologic origin (plant and animal).

$\therefore P(P)=1$, means that all the trace elements found in petroleum ash are included in hydrothermal (magmatic) source, that is igneous origin (abiogenic).

5. Three possibilities were used to trace the origin of petroleum hydrocarbons. These include:

I. SiAl: Silicon and Aluminum which forms silicate minerals in petroleum ash (igneous origin).

II. NiVa: Nickel and Vanadium which replace magnesium in the solid solution to form silicate minerals in petroleum (igneous origin) and that the substitution of magnesium by nickel and vanadium in porhyrins could have taken place during evolution of volcanic rock from magmatic fluid or hydrothermal fluid.

III. TiTi: Tin and Titanium which is derived from cassiterite ore (igneous origin).

IV. The fact that diamond is found within the igneous body as a xenocryst is also an indication of abiogenic origin of petroleum.

\section{CONCLUSION}

According to Robison (1963), the duplex combining features of both organic and inorganic theories may be the final choice. This leads to the conclusion that origin of petroleum hydrocarbons can be traced both organic (biogenic source) and inorganic (Abiogenic source) origin, but this research was found more convincing with abiogenic origin because of the fact most of the trace elements found in petroleum were of inorganic and the data obtained from KVF and those obtained from petroleum ash were mathematically analysed using set notation and matrix method and concluded that, the origin of petroleum hydrocarbons is abiogenic.

The mathematical interpretation of abiogenic oil suggested that the substitution of magnesium by nickel and vanadium in porhyrins could have taken place during evolution of volcanic rock from magmatic fluid or hydrothermal fluid, since substitution of elements likely takes place only at igneous temperature higher than the temperature at which sedimentary rock can be imagined.

In relation to Ringwood scheme (1977), it was concluded that Kassa Volcanic Field (KVF) may be of petroleum hydrocarbons potential (Abiogenic oil) and as such, drilling of Abiogenic oil should be extended to this volcanic field. 


\section{CONTRIBUTION TO KNOWLEDGE}

Using matrix and set notation methods, three possibilities or outcomes in this research have been used to enhance abiogenic origin of petroleum hydrocarbons as according to theories postulated by several authors mentioned above and below are the outlines of the possibilities or outcomes:

1. SiAl: The presence of Silicon ( $\mathrm{Si})$ and aluminum $(\mathrm{Al})$ in the petroleum hydrocarbons indicate that there is a strong bond formation to produce silicate minerals such as magnesium rich olivine, pyroxene and plagioclase which accounts its abiogenic origin.

2. NiVa: The presence of Nickel and vanadium in petroleum hydrocarbons indicates that there is a substitution of Magnesium $(\mathrm{Mg})$ by Nickel $(\mathrm{Ni})$, especially in porphyrins, to produce silicate minerals such as $\mathrm{Ni}$ and $\mathrm{Va}$ rich olivine, pyroxene and sodic plagioclase which account its abiogenic origin.

3. TiTi: The presence of Tin (Sn) and Titanium (Ti) in petroleum hydrocarbns ash indicates an ore minerals such as cassiterites in petroleum hydrocarbons which account its abiogenic origin [cassiterite is product of igneous rock].

\section{RECOMMENDATIONS}

1. I recommend that Ringwood Scheme (1977) should be used to study the geology of Kassa Volcanic Vent (crater) and is similar to that obtained from volcanic tholeiite series produced from fractionation during ascent in island arc as explained by Ringwood (1977).

2. According to Ringwood scheme, that the depth of $80-100 \mathrm{~km}$, there is dehydration of amphibole at temperature greater than or equal to $625^{\circ} \mathrm{c}$ and pressurize of about $25 \mathrm{k}$ bar which released water and eclogite (a dese anhydrons rock having the composition of Basalt), therefore, the released water reacts with abiogenic carbon in the form of carbondioxide to produce abiogenic methane which polymerizes in the presence of magnetite as a catalyst into heavier hydrocarbons. Based on this, I strongly recommend that drilling of abiogenic oil should be extended to magmatic hydrothermal rock (igneous rocks) throughout the world, at least at the depth less than $60 \mathrm{~km}$ beneath the earth.

3. In comparing island arc and Kassa Volcanic Field, the stages in island arc include;

- Tholeiite trend: Basal and Basaltic Andesite

- Calcalkaline with Andesite dominant

- Alkaline trend with hypersthene normative contain $6.5-7 \%$ total alkalis by weight and have a $\mathrm{K}_{2} \mathrm{O} / \mathrm{Na}_{2} \mathrm{O}$ ratio greater than one (1)

The stages in Kassa Volcanic Field include;

- Volcanic Tuff

- Olivine Basalt

- $\quad$ Tholeiite Basalt

- Alkali Olivine Basalt

Based on this, I recommend that drilling of abiogenic oil should also be extended to volcanic vent of Kassa, because island arc of similar fractionation has hydrocarbon potential according to Ringwood explanation. 
International Journal of Advances in Scientific Research and Engineering (ijasre), Volume 7 (6), 2021

4. Since SiAl, TiTi and VaNi are the three possibilities to trace the origin of petroleum, I recommend that drilling of petroleum hydrocarbon should also be extended to the study area, Kassa Volcanic Vent, though may be cost effective because of its igneous nature.

\section{REFERENCES}

1. Ahrens, i. H., 1965, Distribution of the Elements in Our Planet, McGraw-Hill, New York, llOjip.: "6old, T; and Soter, S. (1982).

2. Ahrens, L. H., 1952, The use of ionization potentials - 1. Ionic radii of the elements, Geochim. Cosmochim. Acta, 2, 155-169.

3. Ahrens, L. H., 1964, The significance of the chemical bond for controlling the geochemical distribution of the elements, in Physics and Chemistry of the Earth, Part 1, Vol. 5 (Ahrens, Press, and Runcorn, eds.), Pergamon, New York, pp. 1-54.

4. Arnorsson S., D' Amore F., and Gerardo J. (2000): Isotopic and Chemical Techniques in Geothermal Exploration (ed. S. Arnorsson). Vienna, International Atomic Energy Agency, 351p.

5. Bailey, N.J.L; Krouse, H.R; Evans, C.R; and Rogers, M.A. (1973).-Alternation of crude oil by water and bacteria-evidence for geochemical and isotopic studies. AAPG Bull., 57,1276-1290.

6. Biederman; E.W. (1965) Crude oil composition-a clue to migration. World Oil. 161,78-82.

7. Bowen N. L. and Schairer, J. F., (1935). The system $\mathrm{MgO}-\mathrm{Fe} \mathrm{O}-\mathrm{SiO}_{2}$, Amer. J. Sci., 29 (1935), 151.

8. Bowen N. L., (1928). The later stages of the Evolution of the Igneous Rocks, Journal of Geology xxiii. Supplement, 91 pp.

9. Bowen, N. L. (1914). The system diopside fosterite, silica, Amer. J. Soci., 38. 209.

10. Bowen, N. L., (1935). Ferrosilite as natural mineral, Amer. J. Sci., 29, 151.

11. Bowen, N.L. and Schairer, J.F. 1956. The Evolution of Igneous Rocks. Dover Pub1, New York.

12. Braun, R.L; and Burnham, A.K.(1987). Analysis of chemical reaction kinetics using distribution of activation energies and simpler models. Energy Fuels. 1,153-161.

13. Braun, R.L; and Burnham, A.K. (1990). Mathematical model of oil generation, degradation and expulsion. Energy Fuels. 4,132- 146.

14. Basalts, Vol.1. Interscience, New York, p.271 -323.

15. Buckley, S.E; Hocott, C.R; and Taggart Jr, M.S. (1958). Distribution of dissolved hydrocarbons in sub-surface waters. In: Habitat of oil. Weeks, L.G. (Ed). AAPG, Tulsa, Oklahoma, p. 850-852.

16. Burns, R. G., Clark, R. H.,«and Fyfe, W. S., 1964, Crystal-field theory and application to / problems in geochemistry, in Chemistry of the Earth's Crust, Vemadsky Centennial Symposium. Vol. 2 (Vinogradov, ed.), Moscow, pp. 88-106.

17. Burns, R. G., and Fyfe, W. S., 1966, Distribution of elements in geological processes, t^/Chem. Geol., 1, 49-56. BumS, R. G., and Fyfe, W. S., 1967, Trace element distribution rules and their significance, Chem. Geol., 2, 89-104. Burns, R. G., and Fyfe, W. S., 1967, Crystal-field theory and the geochemistry of transition elements, in Researches in Geochemistry, Vol. 2, (Abelson, ed.), Wiley, New ^ York, pp. 259-285.

18. Carroll, J. (2001). Natural gas hydrates. Gulf Publishing, Boston.

19. Cox, K. G., Bell, J.D. and Pankhurst, R. 1979. The Interpretation of Igenous Rocks. Allen and Unwin, Lond, 450pp.

20. Daly, R. A. (1933). Igneous Rocks and their origin, New York, 1914. Igneous Rocks and the Depth of the Earth, New York.

21. Denbigh, K.G., and J.C.R Turner., (1971). Chemical Reactor Theory - An Introduction (Second Ed.). Cambridge, UK: Cambridge Univ . Press (1971).

22. Dickinson, W.R. (1976). Plate tectonics and hydrocarbon accumulation. AAPG Continuing Education Course Note series, No. 1. DOD Pub; New Delhi; 178 pp.

23. Donnelly, T. W., and J. ). W. Rogers, 1980, Igneous Series in Island Arcs: The Northeastern Caribbean Compared with Worldwide Island-arc Assemblage!, Bull. Volcanol. 43-2:347-382.

24. Dore, A.G; Augustson, J.H; Hermanrud, C; Stewart, D.J; and sylta, O. (Eds) (1990). Basin modeling: advances and applications. Elsevier, Amsterdam.

25. Elson, J., 1969, An empirical bond energy equation, Chem. Commun., 448^450. Fyfe, W. S., 1964, Geochemistry of Solids - an Introduction, McGraw-Hill, New York, 199 pp.

26. Engel, A.E., Engel, C.G. and Havens, R.G. 1965. Chemical Characteristics of Oceanic Basalts and the Upper Mantle. Geol. Soc. Am. Bull. 76,719 - 734 .

27. Espitalie,\}; Laporte, J.L; Madec, M; Marquis, F; Laplat, P; Poulet, J; and Bouteu, A. (1977). Rapid method for source rock characterization and evaluating their petroleum potential and degree of maturity. Rewe del' Institute frncis du petrole, 32,2342 (In French). 
28. Fiske, R. S., and Kinoshita, W. I. (1969) Inflation of Kilauea Volcano Prior to its 1968-8 emption, science, 165, 341-9.

29. Fitton, J. G. 1987. They Cameroon Line, West Africa: A Comparison Between Oceanic and Continental alkaline Volcanism.-ln: J. G. Fitton and B. G. Upton (Editors) Alkaline Igneous Rocks. Geol. Soc. London Spec. Publ. 30,273 - 291.

30. Geol. Surv. Profess. Paper, 127, 117 pp. Curtis, C. D., 1964, Applications of the crystal field theory to the inclusion of trace transition elements in minerals during magmatic differentiation, Geochim. Cosmochim. Acta, $28,389^{\wedge} 03$.

31. Gold, T. (1979). Terrestrial sources of carbon and earthquake out gasing. J. Pet. Geol., 1,3-19.

32. Gold, T. (1999). The deep hot biosphere. Springer-Verlag, New York.

33. Goldschmidt, V. M., 1926, Geochemische Verteilungsyesetze der Elemente VII. Die Gesetze der Kristallochemie, Skrfler Norske Videnskaps-Akad. Oslo, 'I, Mat. Naturv. K1, 2,5-116.

34. Green, D. H., and Ringwood, A. E. (1969). The Origin of basalt magma, Amer. Geophys Union mongr., $489-94$.

35. Green, D. H., ant A. E. Ringwood, 1967, The Genesis of Basaltic Magmas, Contr. Mineralogy and Petrology 15:103-190.

36. Green, D. H: 1967. Effects of High Pressure on Basaltic Rocks. In: H. H. Hess and A. Poldervaart (Editors) Basalts, Vol.1, Interscience, New York, P.271 - 323.

37. Green, D.H. and Ringwood, A.E. 1967. The Genesis of Basaltic Magmas. Contrlb. Mineral. Petrol. 15, $103-190$.

38. Green, J., 1959, Geochemical table of the elements for 1959, 1127-1184.

39. Gupta, S.K; Prasad, G.K; Majumdar, S.K; and Siva Sankar, J. (1998). Tectonics and sedimentation in Krishna-Godavari Basin, India. In: Proc. Nat. Symp. Recent researches in sedimentary basins. Tiwari, N.D (Ed). Indian Petroleum Pub; Dehra Dun, pp. 69-77.

40. Hatch, F:H, Wells, A.K. and Wells, M.K. 1972. Petrology of the Igneous Rocks, Vol. 1, Thomas Murby, London.

41. Hazen TC, Dubinsky EA, Desantis TZ, Andersen GL (2010). Deep - Sea Oil Plume enriches Indigenous oil - degrading bacteria. Science 330; $204-208$.

42. Helgeson, H. Evolution of Irreversible reactions in geochemical processes involving minerals and aqueous solutions. I. thermodynamic relations. Geochim. Geochem Cosmochim, Acta, 32 (1968), pp. 853 - 877.

43. Helgeson, H., Geologic and Thermodynamic Characteristics of the Salton Sea Geothermal System. Am. J. Soc. 266 (1968), pp $129-166$.

44. Hess, P. C., 19*71, Polymer model of silicate melts, Geochim. Cosmochim. Acta, 35, 306.

45. Iddings, J. P., 1895, Absarokite-Shoshonite-Banakite Series, lour. Geology3:935-959.

46. Ito, K.and Kennedy, G.C. 1967. Melting and Phase Relations in a Natural Peridotite to 40 Kilobars. Am. J. Sci. 265 , 519 538.

47. Jakes, P., and J. Gill, 1970, Rare Earth Elements and the Island Arc Tholeiitic Series, Earth and Planetary Sci. Letters 9:1728.

48. Joplin, G. A., 1968, The Shoshonite Association: A Review, Ceol. Soc. Australia Jour. 15(2):275-294.

49. Kempe D. R. S. (1968). Kaersutite from the minverite of Conwall. Min. mag., 36, 874-6.

50. Kennedy, W. Q., 1933, Trends of Differentiation in Basaltic Magmas, Am. Jour. Sci. 25:239-256.

51. Kennedy, W.Q. 1933. Trends of Diffe4entiation in Basaltic Magmas. Am. J.Sci. 25, 239 -256.

52. Kennedy, W.q., 1933. Trends of Differentiation in basaltic magmas. Amer.J. Sci., ser.5 25, $239-56$.

53. Kenney, J.F., Kutcherov, V.G., Bendilani, N.A; and Acekseev, V.A; Proc. Nat.Acad.Sci. USA; 2002 VOL. 99, PP. 1097610981.

54. Kenny, J.F; KutChervov, V.A; Bendeliane, N.A and Alekseev, V.a. 92002). Proc Natl. Sci. Usa. 99, 10976-10981.

55. Kolesnikov A, Kutcherov V.G and Goncharov V.G and Goncharov A.F 2009 Methane-derived hydrocarbons Produced under Upper- mantle conditions Nature Geoscience 2 - 566 - 570.

56. Krauskopf, K. B., 1967, Introduction to Geochemistry, McGraw-Hill, New York," 721 pp.

57. Kutcherov, V.G; Bendeliani, N.A; Alekseev, V.A., and Kenney, J.F., Dokl. Phys. Chem., 2002, vol. 387, Nos. 4 - 6 pp. 331 - 334 (Dokl. Akad. Nauk, 2002, vol. 387, no. 6, pp. 789 - 792).

58. Kuno, H., 1968, Differentiation of Basalt Magmas, in The Poldervaart Treatise on Rocks of Basaltic Composition, vol. 2, Basalts, H. H. Hess and A. Poldervaart, eds., Wiley-lnterscience, New York, pp. 623-688.

59. Kuno, H.I. 1960. High-Alumina Basalts. J. Petrol. I, 121 -141.

60. Kushiro, I., and H. Kuno, 1963, Origin of Primary Basalt Magmas and Classification of Basaltic Rocks, lour. Petrology 4:75-89.

61. MacDonald, G. A., and T. Katsura, 1964, Chemical Composition of Hawaiian Lavas, lour. Petrology 5:82-133.

62. Mason, B., 1966, Principles of Geochemistry, Wiley, New York, 329 pp. 
International Journal of Advances in Scientific Research and Engineering (ijasre), Volume 7 (6), 2021

63. McBirney, A. R., and H. Williams, 1969, Geology and Petrology of the Galapagos Islands, Ceol. Soc. America Mem. 118,197p.

64. Mendele'ev D. (1877). Entstehungund Vorkommen des materials Dtsch. Chem.Gas. Ber; 10, 229.

65. Mendele'ev D. (1902). The principle of chemistry, $2^{\text {nd }}$ English ed; Vol.1, (Translated from $6^{\text {th }}$ Russian ed;) Collier, New York.

66. Miyashiro, A., F. Shido, and M. Ewing, 1969, Diversity and Origin of Abyssal Tholeiite from the Mid-Atlantic Ridge Near $24^{\circ}$ and $30^{\circ}$ North Latitude, Contr. Mineralogy and Petrology 23:38-52..

67. Nackolds, S. R., 1966, The behavior of some elements during fractional crystallization of v/ magma, Geochim. Cosmochim. Acta, 30, 267-278.

68. Peacock, M. A., 1931, Classification of Igneous Rock Series, lour. Ceology 39:54-67.

69. Pitzer K. S., and Brewer, L., (1961). Thermodynamics (2 $2^{\text {nd }}$ edu). M.C. Graw. Hill, New York.

70. Poldervaart (Editors) Basalts, Vol.1 Interscience, New York. P. 163 - 170.

71. Poldervaart, A. ed., 1955a, Crust of the Earth, Geol. Soc. America Special Paper, 62, 762 pp.

72. Poldervaart, A., 1955b, Chemistry of the earth's crust, Geol. Soc. Am. Special Papers, 62, 119-144.

73. Price, Leigh C. (1986). A critical review and proposed working model of surface geochemical exploration. In: unconventional methods in exploration IV. Southern Methodist University, Delias, TX, p 245-304..

74. Prinz, M. 1967. Geochemistry of Basaltic Rocks: Trace Elements. In: H.H. Hes and A. Poldervaart (Editors) Basalts, Vol.1, Interscience, New York, P. 220 - 225.

75. Ramberg H., Devore G., The distribution of $\mathrm{Fe}^{72}$ and $\mathrm{Mg}^{+2}$ in coexisting Olivines and Pyroxenes, J. Geol., 59 (1951), pp. 193 -210 .

76. Rao, C.N.R. (1961). Ultraviolet and visible spectroscopy: chemical applications.

77. Ringwood, A. E., 1955a, The principles governing trace element distribution during mag-/matic crystallization. Part I. The influence of electronegativity, Geochim. Cosmo- ^ chim. Acta, 7, 189-202. Ringwood, A. E., 1955b, The principles governing trace element behavior during magmatic allization. Part II. The role of complex formation, Geochim. Cosmochim. Acta, 7,242-254.

78. Ringwood A. E., (1969). Composition and evolution of the upper mantle, in the Earth's Crust and Upper mantle, ed. P. G. Hart, Amer. Geophys. Union Monogt., 13, 1-17.

79. Ringwood, A.E. 1962. A Model for the Upper Mantle. J. Geophys. Res. 67, 4473 - 4477.

80. Ringwood, A.E. 1975. Composition and Petrology of the Earth's Mantle.McGraw-Hill, New York.

81. Thomas Gold, "Terrestrial Sources of Carbon and Earthquake Outgassing," J. Petrol. Geol., Vol. 1, No. 3, pp.3-19, 1979.

82. I. Kravtsov, "Geochemical Scheme of the Formation of Methane and Liquid Hydrocarbons in Magmatic Processes, and the Basic Criteria of Prospects for Oil and Gas Deposits," in Genesis of Oil and Gas, Nedra Press, Moscow, pp. 314-325, 1967.

83. P. N. Kropotkin, and K. A. Shakhvarstova, "Solid Bitumens, Oil and Fuel Gas in Ultrabasic Intrusions, Trap Brilliants and Volcanic Pipes," in The Problem of Oil Migration and the Formation of Oil and Gas Accumulations, The State Fuel Technical Press, Moscow, pp. 151-164, 1959.

84. N. A Kudryavstev, "Against the Organic Hypothesis of Petroleum Origins," Petroleum Economy, No. 9, Moscow, p. 17, 1951.

85. N. A Kudryavstev, "The Modern State of the Problem of Petroleum Origin," in "Colloquium on Problems of the Origin and Migration of Petroleum," Ukrainian Acad. Sci. Press, Kiev, pp. 38-81, 1955.

86. N. A Kudryavstev, "Geological Evidence of Deep Petroleum Origins," Trans. of the AllUnion Research, Geol. Exploration Petroleum Inst., State Technical Press, Leningrad, p. 210, 1959.

87. N. A Kudryavstev, "Oil, Gas and Solid Bitumens in Igneous and Metamorphic Rocks," State Technical Press, Leningrad, p. 230, 1959.

88. N. A Kudryavstev, "The State of the Question on Genesis of Oil in the Year 1966," in Genesis of Oil and Gas, Nedra Press, Moscow, pp. 262-291, 1967.

89. N. A Kudryavstev, "The Genesis of Oil and Gas," Trans. of the All-Union Research, Geol. Exploration Petroleum Inst., Nedra Press Leningrad, pp. 216, 1973.

90. . V. B. Porfir'yev, "On the Nature of Petroleum," in Problems of Oil and Gas Origin and Conditions of the Formation of Their Deposits, The State Fuel Technical Press, Moscow, pp. 26-40, 1960.

91. B. Porfir'yev, "The Present State of the Problem of Petroleum Formation," in Genesis of Oil and Gas, Nedra Press, Moscow, pp. 292-324, 1967. 
International Journal of Advances in Scientific Research and Engineering (ijasre), Volume 7 (6), 2021

92. B. Porfir'yev, "On a Criticism of the Theory of the Inorganic Origin of Petroleum," in "Colloquium on the Inorganic Origin of Petroleum," Scientific Thought Press, Kiev, pp. 34-54, 1971.

93. V. B. Porfir'yev, "Experience of Geological Analyses of Questions of Petroleum Content," in "Colloquium on the Inorganic Origin of Petroleum," Scientific Thought Press, Kiev, pp. 3-34, 1971. 87

94. V. B. Porfir'yev, “Inorganic Origin of Petroleum,” Bull. Am. Assoc. Petrol. Geol., Vol. 58, No. 1, pp. 3-33, 1974.

95. V. B. Porfir'yev, "Significance of Theoretical Complex of Petroleum Geology in the Solution of the Problem of Commercial Oil Content," in Regularities of Formation and Distribution of Commercial Oil and Gas Fields, Scientific Thought Press, Kiev, pp. 17-27, 1975.

96. V. B. Porfir'yev, V. A. Krayushkin, V. P. Klochko, V. B. Sollogub, A. V. Chekunov, G. N. Ladyzhenskiy and V. I. Sozanskii, "Geological Criteria of Prospects for New Oil and Gas Reserves in the Territory of Ukraine," Scientific Thought Press, Kiev, p. 150, 1977.

97. V. B. Porfir'yev, V. A. Krayushkin, N. S. Erofeev, G. P. Ovanesov, N. A. Eremenko, I. M. Mikhailov, V. A. Moskvich, I. Ye. Kotelnikov, Z. V. Ulybabov and P. M. Zozula, "Perspectives of Prospects for Oil Deposits in the Crystalline Basement of the Pripyat' Basin,” Geological Journal, Vol. 37, No. 5, pp.7-25, 1977.

98. R. H. Dott, Sr. and M. J. Reynolds, "Sourcebook for Petroleum,” Tulsa, p. 471, 1969.

99. E. R. Owen, "Trek of the Oil Finders: A History of Exploration for Petroleum,” Amer. Assoc. Petrol. Geol., Tulsa, p. 1647, 1975.

100.I. Kravtsov and G. I. Voitov, "Evaluation of the Role of Faults in the Gas Exchange between the Lithosphere and the Atmosphere Illustrated in Southern Daghestan," Proc. High. Educ. Institutions. Geology and Exploration, Vol. 19, No. 4, pp. 18-26, 1976.

101.E. B. Chekaliuk, "Petroleum in the Upper Mantle of the Earth," Scientific Thought Press, Kiev, p. 256, 1967.

102.E. B. Chekaliuk, "Energetic Processes in the Interior Part of the Earth and their Role in the Formation of Oil Fields," in Regularities of Formation and Distribution of Commercial Oil and Gas Fields, Scientific Thought Press, Kiev, pp. 66-76, 1975.

103.V. Grinberg, "Study of Conditions for the Synthesis of Hydrocarbons and their Genetic Relations to Kerogen-coal Material," in Regularities of Formation and Distribution of Commercial Oil and Gas Fields, Scientific Thought Press, Kiev, pp. 52-66, 1975.

104.. I. Potapov, "Genesis of Bitumens and Formation of Oil Deposits of the Apsheron in Light of Biochemical, Geochemical, Geophysical, Lithological and Other Regularities," in Proceedings of the Discussion on the Problem of Origin and Migration of Petroleum, Ukrainian Acad. Sci. Press. Kiev. pp. 139-155, 1956.

105.B. Yu. Levin, "Organic Compounds in the Solar System," in Problems of the Origin of Petroleum, Scientific Thought Press, Kiev, pp. 174-222, 1966.

106.V. P. Porfir'yev, V. A. Krayushkin, V. P. Klochko, M. I. Ponomarenko, V. P. Palomar and M. M. Lushpey, "New Directions of Geologic Exploration Work in the Akhtyrka Oilgas Mining District of the Dnieper-Donets Basin," Geol. J., Vol. 42, No.4, pp. 1-11, 1982.

107.V. A. Krayushkin, "On the Oil and Gas Content of the Precambrian Rock in the Dnieper-Donets Basin," Lectures of the Acad. Sci. of U.S.S.R., Vol. 294, No. 4, pp. 931-933, 1987.

108.T. Gold, "Contributions to the Theory of an Abiogenic Origin of Methane and other Terrestrial Hydrocarbons," Proc. 27th International Geological Congress, Vol. 13, Oil and Gas Fields, pp.413-442, 1984.

109.B. Deng, T.J. Campbell, and D.R. Burris, "Hydrocarbon Formation in Metallic Iron/Water Systems", Environmental Science \& Technology, vol. 31, no. 4, pp. 1185-1190, 1997.

110. Art Barber, "Soviets Offer Access to World's Deepest Drill Hole," USA Continental 87Scientific Drilling (CSD) Program, CSD News, Vol. 2, No. 2, p. 7, November 1991.

111.Robert F. Mahfoud, James N. Beck, "Inorganic Origin in Upper Mantle Seen Likely for Solid Hydrocarbon in Syria Plateau Basalt," Oil and Gas Journal, Octobe

112.Zies E. G. (1941). Temperature of volcanoes, Fumaroles and hot springs, Temperature. Its measurement and control in science and industry, P. 377, Rheinhold, New York. 